\title{
De bruikbaarheid van deelmarktinformatie voor het informatiesysteem onderwijs-arbeidsmarkt
}

Citation for published version (APA):

Borghans, L., de Grip, A., \& Hoevenberg, J. (1994). De bruikbaarheid van deelmarktinformatie voor het informatiesysteem onderwijs-arbeidsmarkt. Researchcentrum voor Onderwijs en Arbeidsmarkt, Faculteit der Economische Wetenschappen. ROA Reports No. 13 https://doi.org/10.26481/umarep.1994013

Document status and date:

Published: 01/01/1994

DOI:

10.26481/umarep.1994013

Document Version:

Publisher's PDF, also known as Version of record

\section{Please check the document version of this publication:}

- A submitted manuscript is the version of the article upon submission and before peer-review. There can be important differences between the submitted version and the official published version of record.

People interested in the research are advised to contact the author for the final version of the publication, or visit the DOI to the publisher's website.

- The final author version and the galley proof are versions of the publication after peer review.

- The final published version features the final layout of the paper including the volume, issue and page numbers.

Link to publication

\footnotetext{
General rights rights.

- You may freely distribute the URL identifying the publication in the public portal. please follow below link for the End User Agreement:

www.umlib.nl/taverne-license

Take down policy

If you believe that this document breaches copyright please contact us at:

repository@maastrichtuniversity.nl

providing details and we will investigate your claim.
}

Copyright and moral rights for the publications made accessible in the public portal are retained by the authors and/or other copyright owners and it is a condition of accessing publications that users recognise and abide by the legal requirements associated with these

- Users may download and print one copy of any publication from the public portal for the purpose of private study or research.

- You may not further distribute the material or use it for any profit-making activity or commercial gain

If the publication is distributed under the terms of Article $25 \mathrm{fa}$ of the Dutch Copyright Act, indicated by the "Taverne" license above, 
De bruikbaarheid van deelmarktinformatie voor het informatiesysteem onderwijs-arbeidsmarkt

ROA-R-1994/13

L. Borghans

A. de Grip

J. Hoevenberg

Researchcentrum voor Onderwijs en Arbeidsmarkt

Faculteit der Economische Wetenschappen

Rijksuniversiteit Limburg

Maastricht, december 1994 


\section{CIP-GEGEVENS KONINKLIJKE BIBLIOTHEEK, DEN HAAG}

Borghans, L.

De bruikbaarheid van deelmarktinformatie voor het informatiesysteem onderwijs-arbeidsmarkt / $\mathrm{L}$. Borghans, A. de Grip, J. Hoevenberg. - Maastricht : Researchcentrum voor Onderwijs en Arbeidsmarkt, Faculteit der Economische Wetenschappen, Rijksuniversiteit Limburg. - (Rapport / Researchcentrum voor Onderwijs en Arbeidsmarkt, ISSN 0922-8098 ; ROA-R-1994/13)

Met lit. opg.

ISBN 90-5321-148-9

Trefw.: onderwijs en arbeidsmarkt. 


\section{Inhoudsopgave}

Bladzijde

Verantwoording

1 Inleiding

2 Theoretische achtergrond voor het gebruik van externe expertise 5

2.1 Inleiding

2.2 'Judgemental forecasting' literatuur

2.3 Integratie van deskundigenoordelen in de bedrijfstakprognoses van het Centraal Planbureau

2.4 Conclusies en verdere werkwijze met betrekking tot het raadplegen van externe expertise

3 Aandachtspunten binnen het ROA-informatiesysteem 13

3.1 Inleiding 13

3.2 Beroepsinformatie 13

3.3 Opleidingsinformatie 16

3.4 Conclusie 18

4 Deelmarktexpertise 21

4.1 Inventarisatie expertisebronnen 21

4.2 Gesprekken met deskundigen 23

5 Conclusie $\quad 27$

$\begin{array}{ll}\text { Literatuur } & 31\end{array}$

Bijlage A 33 
$\ldots$ 


\section{Verantwoording}

In opdracht van het Ministerie van Onderwijs, Cultuur en Wetenschappen (O.C. \& W.), het Landelijk Dienstverlenend Centrum voor Studie- en Beroepskeuzebegeleiding (LDC) en het Centraal Bureau voor de Arbeidsvoorziening (CBA) heeft het Researchcentrum voor Onderwijs en Arbeidsmarkt (ROA) de afgelopen jaren het informatiesysteem onderwijs-arbeidsmarkt ontwikkeld.

De laatste jaren hebben binnen het informatiesysteem, onder andere door het beschikbaar komen van nieuwe databronnen en de evaluatie van de prognosesystematiek, ingrijpende wijzigingen plaatsgevonden om tot verbetering van de arbeidsmarktprognoses te komen. Mede door het relatief hoge aggregatieniveau van de prognoses is vanuit de begeleidingscommissie de wens geuit de mogelijkheden te onderzoeken om externe expertise in te zetten om de arbeidsmarktprognoses naar opleiding en beroep te verbeteren en/of nader te specificeren. Dit rapport is het resultaat van deze verkenning van mogelijkheden en onmogelijkheden om externe expertise in te zetten in het informatiesysteem onderwijs-arbeidsmarkt. Het rapport laat zien op welke momenten het inschakelen van externe expertise tot een verbetering van de kwaliteit zal kunnen leiden en voor welke deelgebieden van het informatie-systeem onderwijs en arbeidsmarkt het inzetten van externe expertise van belang kan zijn. Vervolgens zullen de resultaten van enige gesprekken met externe experts worden beschreven. Tenslotte bevat dit rapport een overzicht van mogelijke bronnen van externe expertise.

De auteurs van dit rapport danken de leden van de begeleidingscommissie voor hun inbreng bij het totstandkomen van dit rapport. 
$\ldots \ldots$ 


\section{Inleiding}

De arbeidsmarktprognoses die de kern vormen van het informatiesysteem onderwijs-arbeidsmarkt, zijn gebaseerd op prognosemodellen voor de uitbreidingsvraag, de vervangingsvraag en de instroom naar beroep en opleiding. Bij het opstellen van de prognose dient echter rekening te worden gehouden met het spanningsveld tussen aan de ene kant hetgeen theoretisch wenselijk wordt geacht en aan de andere kant hetgeen, gezien de beschikbare data, haalbaar is. Al sinds de eerste opzet van het informatiesysteem onderwijs-arbeidsmarkt in 1987 hebben er ontwikkelingen plaatsgevonden om de kwaliteit van de prognoses te verbeteren. Het ROA streeft er daarbij naar om vanuit een theoretisch kader prognosemodellen op te stellen, die op hun economische merites beoordeeld kunnen worden. Om deze pretenties te staven, voert het ROA een bewust publicatiebeleid, gebaseerd op een volstrekte openheid ten aanzien van de gebruikte onderzoeksmethoden. Door het uitbrengen van werkdocumenten, research-memoranda, artikelen in nationale en internationale tijdschriften en presentaties op nationale en internationale conferenties wordt, in aanvulling op de besprekingen in de begeleidingscommissie, inhoud gegeven aan deze wetenschappelijke verantwoording over de gebruikte en ontwikkelde methodieken. Deze activiteiten bieden het ROA ook de mogelijkheid feedback te krijgen op de gevolgde aanpak en om alternatieve methoden te verkennen.

Ondanks het feit dat de opzet en methodiek van het informatiesysteem onderwijs-arbeidsmarkt de afgelopen zeven jaar reeds duidelijk is uitgekristalliseerd, blijft het van belang de systematiek te blijven evalueren, opdat verbeteringen voor volgende prognoseperioden gerealiseerd kunnen worden. Het is niet alleen van belang om deze evaluaties ex post uit te voeren, zoals recentelijk is gedaan door Borghans, Van Eijs en De Grip (1994). Tevens is het belangrijk vooraf enig inzicht te hebben in de plausibiliteit van de, op basis van de gehanteerde modellen, verkregen prognoses. Dit geldt temeer wanneer er op basis van de beschikbare databronnen in het informatiesysteem slechts opleidings- of beroepscategorieën kunnen worden onderscheiden die vanuit arbeidsmarktoogpunt erg heterogeen zijn. Een nauwgezette ex ante beoordeling van de plausibiliteit zou dan kunnen leiden tot een tijdige aanpassing van het model, of een nuancering van de prognoseresultaten ${ }^{1}$.

Een mogelijkheid om tot een verbetering van de prognoses te komen is het raadplegen van externe expertise. Het gaat daarbij niet primair om deskundigheid op het gebied van de te hanteren methoden, maar om enerzijds de beschikbaarheid van relevante arbeidsmarktinformatie met betrekking tot een specifiek arbeidsmarktsegment en anderzijds de meer algemene expertise op het gebied van de actuele arbeidsmarktsituatie op een bepaalde deelmarkt en de te verwachten arbeidsmarktontwikkelingen op het desbetreffende segment.

Met dit rapport stelt het ROA zich ten doel om een inventarisatie te maken van de beschikbare segmentspecifieke informatiebronnen voor het ROA-informatiesysteem en na te gaan op welke wijze het best gebruik gemaakt kan worden van deze expertise. Uitgaande van de wenselijkheid de sectorale werkgelegenheidsprognoses binnen het informatiesysteem te baseren op de middellange-termijnprognoses van het Centraal Planbureau, gaat het daarbij primair om expertise met betrekking tot een bepaald beroeps- of opleidingssegment van de arbeidsmarkt.

1. Dit laatste is reeds eerder gedaan bij de prognoses van de arbeidsmarktperspectieven voor de opleidingstypen $\mathrm{HBO}$ onderwijs, WO onderwijs en HBO technische bedrijfskunde (zie ROA, 1993). 
Bij het inschakelen van experts dient echter wel de nodige voorzichtigheid betracht te worden. De prognoses van het ROA komen tot stand door een zorgvuldige analyse van alle bij het ROA aanwezige data, waaruit relaties tussen de diverse relevante grootheden worden afgeleid, die naar verwachting ook in de toekomst zullen standhouden. Deze analyses hebben betrekking op de verschillende opleidingsen beroepssegmenten over de volle breedte van de arbeidsmarkt. Deze geïntegreerde aanpak bij het opstellen van de prognoses heeft als voordeel dat de prognoses per opleidings- en beroepscategorie onderling consistent zijn. Dit betekent ook dat een wijziging van de prognose voor de ene deelmarkt gevolgen kan hebben voor alle deelmarkten. Opinies van experts met betrekking tot een specifiek arbeidsmarktsegment zullen dan ook zorgvuldig bekeken dienen te worden op hun implicaties voor de prognoses voor de andere segmenten. De inzichten van bepaalde experts zullen derhalve alleen meegenomen moeten worden als deze inzichten gebaseerd zijn op zorgvuldige analyses van aspecten die in onvoldoende mate door het ROA zijn meegenomen bij het opstellen van de prognoses.

De inschakeling van externe expertise kan er ook toe leiden dat er enige nuancering kan plaatsvinden van de arbeidsmarktinformatie naar beroepsklasse of opleidingstype, voor zover er sprake is van duidelijke verschillen tussen de onderliggende beroepen of opleidingen. Dit is in het verleden reeds gebeurd met de meer specifieke lerarenprognoses die in opdracht van het Ministerie van Onderwijs Cultuur en Wetenschappen (OCW) werden opgesteld. Vooral voor beroepsklassen en opleidingstypen die heterogeen van samenstelling zijn kan een nadere diversificatie de prognoses aanzienlijk verrijken.

Een bijzonder geval waarbij het oordeel van deskundigen van groot belang is betreft de arbeidsmarktperspectieven van nieuwe opleidingen of beroepen. Bij het ROA is reeds herhaaldelijk onderzoek gedaan naar de arbeidsmarktperspectieven van nieuwe academische studierichtingen (Borghans en Wiendels, 1993, Kruisinga, Ramaekers en Van der Velden, 1993 en Borghans en Hoevenberg, 1994). Omdat in het geval van een nog op te richten studierichting per definitie geen data beschikbaar zijn die als basis kunnen dienen voor een econometrische analyse, is de inbreng vanuit gesprekken met deskundigen bijzonder waardevol. Deze bijdrage kan op twee wijzen gestalte krijgen.

Ten eerste kan een analyse van de arbeidsmarktperspectieven van nieuwe opleidingen worden gemaakt door een vergelijking te maken met andere situaties, bijvoorbeeld de arbeidsmarkt van vergelijkbare studierichtingen of de arbeidsmarkt van dezelfde studierichting in andere landen. Om een dergelijke analyse uit te kunnen voeren is het van cruciaal belang dat het geselecteerde vergelijkingsmateriaal inderdaad aansluit bij de eigenschappen van de beoogde nieuwe studierichting. Gezien het grote belang van de vakinhoudelijke beoordeling dat hierbij speelt, kan het inschakelen van een inhoudsdeskundige (met betrekking tot de onderwijskant) hierbij een wezenlijke rol spelen. Verder blijken inhoudsdeskundigen vaak op de hoogte te zijn van specifieke analyses of databestanden met betrekking tot bepaalde interessante vergelijkbare situaties in binnen- en buitenland.

Ten tweede is het uiteraard ook mogelijk om een oordeel te vragen aan personen die deskundig zijn met betrekking tot de vraagkant van de arbeidsmarkt voor de nieuwe studierichting, bijvoorbeeld omdat ze een potentiële werkgever van de afgestudeerden van de opleiding zijn. Hoewel een dergelijke methode waardevol is voor het verkrijgen van zeer specifieke informatie met betrekking tot de arbeidsmarkt voor de betreffende studierichting en ze daardoor ook nuttige informatie oplevert voor de invulling van het curriculum, heeft ze ook enkele nadelen. De oordelen die deskundigen geven lopen vaak sterk uiteen, doordat het inzicht in de markt sterk kan verschillen van persoon tot persoon. Verder lijkt het inzicht van deskundigen sterk te worden beïnvloed door de positie die ze zelf bekleden. Bovendien blijkt het bijzonder moeilijk om op basis van deskundigeninterviews de arbeidsmarktsituatie te kwantificeren. In de gevallen waar juist een dergelijke kwantificering voorop staat, dienen 
deskundigeninterviews dan ook altijd aangevuld te worden met data-analyses.

De afgelopen jaren heeft het ROA reeds een uitgebreid netwerk opgebouwd met instanties die beschikken over de benodigde informatie. Hierbij valt natuurlijk in de eerste plaats te denken aan het CBS (EBB-enquête, deelname niet-regulier onderwijs), het CPB (Bedrijfssectorprognoses) en het Ministerie van Onderwijs, Cultuur en Wetenschappen (Referentieraming). Daarnaast zijn er ook informatieuitwisselingsafspraken met andere onderzoeksinstituten zoals de OSA, het SCO en het IVA. Ten slotte is er natuurlijk segmentspecifieke expertise aanwezig binnen het ROA zelf (schoolverlatersenquêtes, onderzoeken op specifieke marktsegmenten, etc).

In het algemeen kan echter gesteld worden dat onderzoeksbureaus en hun opdrachtgevers en beroepsverenigingen, werkgeversorganisaties, koepelorganisaties e.d., mogelijk nog over door het ROA onontgonnen bronnen met relevante informatie kunnen beschikken. Om een optimaal gebruik te kunnen maken van de informatie die bij dergelijke instellingen beschikbaar is, is het gewenst reeds bij de start van een prognosecyclus over de bestaande informatie te kunnen beschikken. Het lijkt dan ook raadzaam in een zeer vroeg stadium contacten te leggen met de betreffende experts van deze instellingen.

De verdere opbouw van dit rapport is als volgt. Eerst wordt in hoofdstuk 2 getracht om een onderbouwing te geven voor de wijze waarop externe segmentspecifieke expertise het beste zou kunnen worden ingeschakeld ten behoeve van de ex ante beoordeling van de plausibiliteit van de arbeidsmarktprognoses van het ROA. Vervolgens wordt in hoofdstuk 3 een inventarisatie gemaakt van de verschillende segmenten in het ROA-informatiesysteem waarvan de prognose en de realisatie sterk van elkaar afwijken. In principe zijn dit de beroepen en opleidingen waarvoor de behoefte aan externe data en expertise het meest duidelijk is gebleken. In hoofdstuk 4 wordt een globaal overzicht gegeven van de mogelijke bronnen voor informatie en expertise met betrekking tot de verschillende beroepsklassen en opleidingstypen. Tevens worden de criteria geformuleerd op basis waarvan het belang kan worden aangegeven om met een bepaalde instelling contact te leggen. Vervolgens wordt in dit hoofdstuk kort verslag gedaan van de resultaten van enkele verkennende gesprekken met vertegenwoordigers van geselecteerde instellingen over de mogelijkheden om van externe segmentspecifieke databronnen en expertise gebruik te kunnen maken. Ten slotte worden in hoofdstuk 5 de belangrijkste conclusies van deze verkennende studie kort samengevat. 
$\ldots \ldots$ 


\section{Theoretische achtergrond voor het gebruik van externe expertise}

\subsection{Inleiding}

In dit hoofdstuk wordt nader ingegaan op de verschillende mogelijkheden die er zijn voor het inschakelen van externe expertise. In paragraaf 2.2 wordt aan de hand van de internationale literatuur aangetoond dat er vele mogelijkheden zijn om gebruik te maken van externe expertise bij het opstellen van prognoses. Echter, deze literatuur toont tevens aan dat het gebruik maken van externe expertise niet noodzakelijkerwijs tot betere prognoses leidt, maar soms zelfs slechtere resultaten tot gevolg heeft. In paragraaf 2.3 wordt vervolgens ingegaan op de ervaringen die het Centraal Planbureau heeft met het raadplegen van externe expertise. Ten slotte wordt in paragraaf 2.4 getracht een antwoord te vinden op de vraag wat voor het ROA de beste methode van het raadplegen van externe expertise is.

\section{2 'Judgemental forecasting' literatuur}

Onderzoek van Ahlburg en Land (1992) heeft aangetoond dat terughoudendheid bij het inschakelen van experts niet ongegrond is. 'In the general forecasting literature, domain expertise has been shown to add little to forecast accuracy. However, it seems that expert judgment can reduce forecast error if the judgement is structured.' Ahlburg en Land wijzen in dit verband op het optreden van een assumption drag: verwachtingen over de toekomstige ontwikkelingen worden sterk beïnvloed door de recente ontwikkeling of de actuele situatie.

Uit onderzoek van Collopsy en Armstrong (1992) blijkt echter dat goed gestructureerde expertconsultatie tot betere resultaten leidt dan het alleen gebruiken van experts of het alleen gebruiken van een enkel statistisch model. Hughes (1993) bevestigt dit beeld nog eens als hij schrijft: 'relatively simple single cell methods have to be used to extrapolate trends in occupational shares. It has been found from experience that these methods give the best results when combined with expert knowledge of the current position in occupational labour markets and judgement of what is likely to happen during the projection period.'

De onderzoeksresultaten van O'Conner, Remus en Griggs (1993) laten zien dat indien alleen wordt afgegaan op experts, dit leidt tot significant slechtere uitkomsten dan wanneer alleen gebruik wordt gemaakt van statistische modellen: 'People seemed to change their forecasts in response to random fluctuations in the time series, identifying a signal where it did not exist.' Het experiment van O'Conner, Remus en Griggs heeft betrekking op het maken van prognoses gebaseerd op tijdreeksen. Een tiental tijdreeksen, sommige met trendbreuken, zijn aan een aantal experts voorgelegd en zijn daarnaast met twee modellen doorgerekend. De resultaten laten zien dat de gemiddelde absolute fout voor de modellen aanzienlijk lager lag (voor één model zelfs significant lager) dan voor de prognoses van de experts.

McNees (1990) is van mening dat een combinatie van modellen en experts tot betere resultaten leidt, mits men een goed antwoord heeft op de volgende vragen:

1. Wanneer en onder welke omstandigheden levert het raadplegen van experts informatie op met een voorspellende waarde die hoger is en verder gaat dan het formele model alleen zou kunnen genereren?

2. Hoe kan de imperfecte informatie van experts gecombineerd worden met de imperfecte informatie van het model, zodat de voorspellende kracht zo groot mogelijk wordt? 
Uit het onderzoek van McNees blijkt eveneens dat experts nogal eens geneigd waren om teveel gewicht te geven aan specifieke actuele omstandigheden. Door de grote waarde die de experts aan de zeer recente, of op korte termijn te verwachten, gebeurtenissen toekennen blijken experts de modeluitkomsten in te sterke mate aan te passen. Ook verschillen de uitkomsten van het combineren van prognoses van experts en voorspellingen op basis van statistische modellen nogal sterk tussen de verschillende macro-economische grootheden waarop het onderzoek betrekking heeft. Illustratief op dit punt is ook de door het CPB geconstateerde slechte voorspelkracht op geaggregeerd niveau van de bij de ERBO-enquête van de Kamers van Koophandel aan de bedrijven gevraagde verwachte ontwikkeling van het aantal werkzame personen.

De literatuur beschrijft verschillende methoden om experts te raadplegen. Sniezek (1989) beschrijft een vijftal methoden om tot groepsstandpunten te komen:

1. Consensus

Dit is een zogenaamde oplossing-georiënteerde methode waarbij net zo lang gediscussieerd wordt totdat er een unaniem standpunt van de hele groep is. Het gevaar van deze methode is dat de groep individuele voorspellende waardeoordelen gaat bediscussiëren en evalueren zonder adequaat aandacht te besteden aan de factoren die de toekomstige waarde van een variabele kunnen beïnvloeden.

2. Dialectic

Deze probleem-georiënteerde methode probeert het probleem dat zich voordoet bij de consensusmethode te ondervangen door van een bepaalde modeluitkomst uit te gaan en de groep te laten discussiëren over de factoren die er toe kunnen leiden dat de werkelijke uitkomst hoger of lager wordt.

3. Dictator

Bij deze methode wordt in eerste instantie gediscussieerd om het 'beste' groepslid aan te wijzen, waarbij er van uit wordt gegaan dat degene die als beste wordt aangewezen het uiteindelijke oordeel van de groep bepaalt. Het nadeel van deze methode is dat de effectiviteit afhangt van het vermogen van de groep om het 'beste' lid te selecteren.

4. Delphi

Dit is een methode waarbij de experts die deelnemen aan de discussie anoniem blijven voor elkaar. De reden voor deze anonimiteit is het gevaar dat een normale groepsdiscussie kan leiden tot kwalitatief zeer slechte uitkomsten doordat experts die zeer veel zelfvertrouwen of status uitstralen, veel invloed op de discussie kunnen uitoefenen, zelfs als hun mening onjuist is. De groepsleden worden wel met de meningen van de anderen geconfronteerd, met het doel daarop te reageren. Dit proces gaat door totdat er geen verandering in de meningen van de groepsleden meer optreedt.

5. Collective

Deze methode sluit iedere interactie tussen experts uit. De uitkomst is simpelweg het gemiddelde van de individuele meningen van de experts over een bepaald onderwerp.

Uit het onderzoek van Sniezek blijkt dat de dictatormethode de beste resultaten oplevert. Armstrong (1985) concludeert daarentegen dat wanneer de meningen van meerdere experts worden gemiddeld, de resultaten beter worden. Een verklaring voor deze verschillende onderzoeksuitkomsten kan gevonden worden in de verschillende vakgebieden waarop het onderzoek betrekking heeft en de wijze waarop het onderzoek is uitgevoerd. Veel van het onderzoek naar de resultaten van expertaanpassingen wordt gedaan in een laboratoriumopstelling, waardoor de externe effecten buitengesloten kunnen worden. Dit komt natuurlijk niet overeen met de situatie zoals deze zich in de werkelijkheid voordoet, omdat een factor als de maatschappelijke positie van de experts wel degelijk invloed op de resultaten heeft. 
Bij het opstellen van de bevolkingsprognoses door het CBS wordt gebruik gemaakt van externe experts. Het gaat hierbij om oordelen gebaseerd op intuïtie of andere modellen. De kwaliteit van deze oordelen is wisselend en meestal zijn de uitspraken vooral kwalitatief. Slechts zelden worden er aantallen genoemd. De functie van het raadplegen van experts bij het CBS is dan ook vooral om na te gaan of rekening is gehouden met alle beschikbare achtergrondinformatie.

\subsection{Integratie van deskundigenoordelen in de bedrijfstakprognoses van het Centraal Planbureau}

Bij het Centraal Planbureau (CPB) bestaat een lange traditie om op basis van zowel de inzichten van deskundigen als op basis van een econometrisch model prognoses te maken. Voorbeelden hiervan zijn de prognoses die jaarlijks in het Centraal Economisch Plan verschijnen. In deze paragraaf wordt, als voorbeeld van de werkwijze van het $\mathrm{CPB}$, ingegaan op de totstandkoming van bedrijfstakprognoses, mede omdat deze een belangrijke bron vormen voor de ROA-prognoses.

De bedrijfstakprognoses worden opgesteld door Hoofdafdeling III, Bedrijfstakken. Deze hoofdafdeling kent vijf afdelingen, Bedrijfstakkencoördinatie, Bouw, Industrie, Diensten en Landbouw en voedingsmiddelen. De afdeling bedrijfstakkencoördinatie vervult een centrale rol in de totstandkoming van onderling consistente bedrijfstakramingen. Bij het opstellen van prognoses wordt onderscheid gemaakt tussen de korte-termijn-prognoses (voor het lopende en daaropvolgende jaar) en de middellange-termijn-prognoses voor de komende vier jaar.

Voor de korte-termijn-prognoses worden in eerste instantie ramingen gemaakt voor de afzonderlijke bedrijfstakken. Per afdeling werken hieraan 2 à 3 personen gedurende een deel van het jaar. Deze houden zich op de hoogte van de ontwikkelingen in de desbetreffende sector. Dit doen ze door bestudering van de relevante literatuur en door regelmatige contacten met personen in het desbetreffende werkveld. Deze interne sectordeskundigen van het CPB geven op basis van hun inzichten een overzicht van de ontwikkelingen van alle relevante grootheden voor de korte termijn.

Een deel van deze sectorspecifieke ramingen is echter impliciet of expliciet gebaseerd op veronderstellingen over andere sectoren. In directe zin geldt dit voor de onderlinge leveringen, maar ook indirect kunnen er dergelijke samenhangen bestaan. Op de afdeling bedrijfstakcoördinatie worden daarom alle sectorprognoses in elkaar geschoven zodat geconstateerd kan worden waar deze discrepanties zich voordoen. Met 'loven en bieden' op grond van de argumenten van de betreffende specialisten wordt consensus gezocht. Slechts bij hoge uitzondering wordt deze niet bereikt. In dat geval moet de directie de knoop doorhakken. Wel wordt telkens bijgehouden in welke mate de prognoses zijn bijgesteld. Dit proces, dat overigens vrij tijdrovend is, leidt dus tot een verzameling onderling consistente bedrijfstakprognoses, die geaggregeerd ook een macro-economische prognose vormen.

Voor de macro-economische prognoses gebruikt het CPB echter ook het FKSEK-model (CPB, 1992). Het FKSEK-model is een macro-economisch model waarin slechts enkele sectoren worden onderscheiden. Het is vooral bedoeld voor puur macro-economische prognoses (zie CPB, 1992). Dit model wordt gedraaid door de afdeling Conjunctuur (van hoofdafdeling II, Korte termijn). Overleg tussen beide afdelingen, bedrijfstakken en conjunctuur dient hier weer tot een consensus te leiden. De beide macro-economische ramingen worden zodanig aan elkaar aangepast dat ze uiteindelijk dezelfde prognoses opleveren. Als er bij de sectorprognoses een bijstelling plaats moet vinden betekent dit dat ook de onderliggende prognoses van de sectordeskundigen bijgesteld moeten worden. Een van de criteria die hierbij gehanteerd kan worden is dat prognoses die in de eerste ronde het meest hebben moeten inleveren, als eerste weer wat terug krijgen. 
Voor de prognoses op middellange-termijn wordt een vergelijkbare procedure gevolgd. Een opvallend punt is dat bij deze langere prognoseperiode de rol van de sectordeskundigen geringer wordt. In plaats hiervan wordt er voor de bedrijfstakkenprognoses gebruik gemaakt van het bedrijfstakkenmodel Athena. De voornaamste confrontatie vindt dan plaats tussen het bedrijfstakken-model Athena (CPB, 1990) en FKSEK (ditmaal door de afdeling Middellange termijn van de hoofdafdeling I, Modelontwikkeling en economisch analyse). Ook hier wordt door een proces van loven en bieden op basis van de onderliggende argumenten consensus gezocht tussen de uitkomsten van beide modellen. Naast verschillen die ontstaan vanwege het verder gedesaggregeerde bedrijfstakniveau waarop Athena werkt, zijn er ook enkele cruciale verschillen op het macro-vlak tussen beide modellen. Overigens vormen dergelijke belangrijke verschillen tussen de modellen aanleiding om dit soort relaties grondig nader te onderzoeken.

Bij de middellange-termijn-prognoses spelen de bedrijstakdeskundigen dus een kleinere rol. Wel worden de uitkomsten van de modellen uiteindelijk ook aan hen voorgelegd om de plausibiliteit te toetsen en wordt het einde van de korte-termijn-prognoses als startpunt voor de modellen gekozen, zodat de deskundigheid van de sectorspecialisten met betrekking tot de korte termijn wel tot uitdrukking komt in de middellange-termijn-prognoses.

Om de beide modellen, Athena en FKSEK op één spoor te krijgen, moet een groot deel van de vergelijkingen in deze modellen worden bijgesteld. Er worden bij het Planbureau twee methoden gehanteerd om dergelijke ad hoc aanpassingen aan te brengen in de vergelijkingen ${ }^{2}$. Er kunnen autonomen worden toegevoegd en men kan de residuen van vergelijkingen vastzetten. Bij het gebruik van autonomen wordt aan de jaarlijkse groeivoet een additionele waarde toegekend. Bij het vastzetten van de residuen worden de prognoses van de te verklaren variabele ingevoerd en zoekt de computer de bijbehorende storingstermen. Deze storingstermen hangen af van de waarden van de verklarende variabelen. Veranderingen in de verklarende variabelen hebben daarom bij deze methode geen invloed meer op de uitkomst van de vergelijking. Het komt er op neer dat de vergelijking wordt genegeerd. Bij het gebruik van autonome variabelen blijt de invloed van verklarende variabelen op de vergelijking ongewijzigd en verandert alleen het absolute niveau van de uitkomst. Bij de aanpassing van de residuen wordt bijgehouden hoe groot de berekende storingstermen zijn. Deze waarden vormen een indicatie voor de spanning tussen het onaangepaste model en de opgelegde uitkomsten.

Naast het gebruik om Athena en FKSEK voor het opstellen van het Centraal Economisch Plan gelijkluidend te maken, zijn er voor het CPB een vijftal redenen om ook bij het afzonderlijk gebruik van de modellen ad hoc aanpassingen aan te brengen. De eerste reden betreft de plausibiliteit van de prognoses. Hierbij kunnen de interne sectordeskundigen op specifieke deelgebieden een belangrijke rol spelen. Ten tweede kan het gehanteerde aggregatieniveau een reden vormen voor een bijstelling. Onder een bepaalde vergelijking voor een bepaalde bedrijfstak gaan vaak meerdere deelprocessen schuil. Een voorbeeld hiervan is de landbouw waarbinnen de tuinbouw thans een veel crucialere rol speelt dan in de jaren '60, terwijl deze deelsector qua structuur sterk verschilt van de veehouderij en de akkerbouw. Ten derde kunnen residuen in het recente verleden aanleiding zijn om bepaalde vergelijkingen (tijdelijk) bij te stellen. Een systematische afwijking in een vergelijking kan wijzen op een structurele verandering in de geschatte relatie. Als er om deze reden veel moet worden bijgestuurd is dat eigenlijk aanleiding om de vergelijking opnieuw te schatten. De vraag of een vergelijking feitelijk ook gereviseerd kan worden hangt echter af van de prioriteit die een dergelijke revisie heeft. Deze prioriteit

2. Zie ook CPB, 1983, hoofdstuk V, dat volledig gewijd is aan het maken van prognoses in de praktijk. 
hangt sterk samen met de rol die de desbetreffende vergelijking in het totale model speelt. Een vierde reden om vergelijkingen ad hoc bij te stellen, is het beschikbaar komen van nieuwe informatie. Bij Athena moet deze aanpassing handmatig geschieden, maar bij FKSEK worden dergelijke bijstellingen automatisch gemaakt. Ten slotte kunnen incidentele gebeurtenissen een aanleiding vormen om een vergelijking bij te stellen. Bepaalde toekomstige gebeurtenissen zullen een sterke invloed op de variabelen in het model hebben. Een voorbeeld hiervan is de afschaffing van de winkelsluitingswet. Gebrek aan historische gegevens maakt het onmogelijk om de effecten van een dergelijke maatregel te schatten. In plaats daarvan wordt daarom een 'guesstimate' gebruikt. De haalbaarheid van dergelijke aanpassingen hangt echter sterk af van de vraag hoe duidelijk het verband tussen het incident en de variabelen is. Als er zowel positieve als negatieve invloeden zijn waarvan het saldo moeilijk te voorspellen valt, kan een dergelijke aanpassing niet doorgevoerd worden. Voor dergelijke invloeden rest geen andere oplossing dan het plaatsen van een voetnoot bij de prognoses dat de invloed van deze incidenten niet is geïncorpereerd in de prognoses.

Concluderend kan gesteld worden dat bij de prognoses die worden opgesteld door het CPB de invloed van expertise van met name de interne sectordeskundigen en de uitkomsten van andere prognosemodellen aanzienlijk is. Uiteindelijk bevat het Athena-model weinig vergelijkingen die niet in zekere zin zijn aangepast. Bij de middellange-termijn-prognoses neemt de invloed van de interne sectordeskundigen echter aanzienlijk af. De werkwijze van het CPB is wel zeer arbeidsintensief en vergt naast de nodige expertise op de van belang zijnde deelgebieden ( 2 à 3 personen per bedrijfstak) een complexe coördinatie. Het totstandkomen van de prognoses vergt daarom veel tijd en maakt het noodzakelijk dat bijvoorbeeld met betrekking tot de exogenen in eerste instantie met voorlopige cijfers gewerkt moet worden.

\subsection{Conclusies en verdere werkwijze met betrekking tot het raadplegen van externe expertise}

Zoals uit de literatuurstudie en de ervaringen van het Centraal Planbureau blijkt kan het inschakelen van experts van nut zijn, mits aan de nodige eisen van zorgvuldigheid is voldaan. Alvorens een selectie van de te raadplegen experts te maken, dient er een onderscheid te worden gemaakt naar de gebieden waar het gebruik van experts een duidelijke meerwaarde zou kunnen hebben. Voor het maken van prognoses kunnen vier factoren worden onderscheiden die van fundamenteel belang zijn voor de kwaliteit van prognoses, te weten:

- de kwaliteit van de gebruikte data;

- de aard van de gebruikte modellen;

- de variabelen die in het model worden opgenomen;

- het bijstellen van de uitkomsten van de prognoses vanwege incidentele gebeurtenissen en nieuwe informatie.

Voor het ROA-informatiesysteem lijkt het op dit moment niet nodig om experts te raadplegen op het gebied van de aard van de gebruikte modellen. Zoals in de inleiding reeds werd aangegeven, gebeurt dit in feite al regelmatig door het presenteren onderzoekspapers op wetenschappelijke congressen en de bespreking van de onderzoeksmethodieken in de begeleidingscommissie van het informatiesysteemproject. Experts dienen dan ook gezocht te worden op het gebied van de beschikbare additionele databronnen en voor het aangeven van de voor de arbeidsmarktontwikkelingen op een bepaalde deelmarkt relevante (specifieke) factoren. Binnen de groep van experts kan onderscheid worden gemaakt naar de aard van kennis die deze bezitten. Als eerste is er de algemeen-expert. Dit is een deskundige met zeer veel algemene kennis van een bepaald arbeidsmarktsegment. Verder is er nog de bron-expert. Dit is een persoon die beschikt over data over een bepaald segment en/of specifieke 
prognoses. Om de kennis van experts optimaal te kunnen gebruiken is een verdere specificatie van het benodigde kennisveld noodzakelijk en dient goed in kaart gebracht te worden op welke informatiebronnen de externe expertise is gebaseerd.

Gezien de literatuurstudie lijkt de dictator-methode de meest voor de hand liggende methode voor het inschakelen van experts te zijn. Echter, er kleven de nodige bezwaren aan deze methode, te weten:

1. Het is in de meeste gevallen niet mogelijk om voor één bepaald segment voldoende deskundigen te vinden om deze methode toe te kunnen passen.

2. Gezien het grote aantal beroeps- en opleidingscategorieën dat binnen het informatiesysteem wordt beschreven, is het ondoenlijk om voor ieder segment een groep externe experts in te schakelen.

3. Het is veelal niet mogelijk een toonaangevende expert aan te wijzen die niet zelf een belangenpositie inneemt als actor op het desbetreffende arbeidsmarktsegment.

4. Van sectordeskundigen kan niet verwacht worden dat zij het gehele ROA-informatiesysteem kunnen overzien. Het is van groot belang dat de dictator kan aangeven of de discussie moet leiden tot daadwerkelijke aanpassingen. Als er binnen een segment echter wordt besloten tot aanpassing moet de 'dictator' echter ook de consequenties voor de andere segmenten kunnen overzien. Dit maakt het in feite onmogelijk om een externe deskundige als dictator aan te wijzen.

Aangezien het al erg moeilijk lijkt om één deskundige op een bepaald segment te vinden, lijkt het dan ook meer voor de hand te liggen om de dialectic-methode toe te passen. Bij deze methode is het mogelijk om aan de hand van de voorlopige prognoses met experts te discussiëren over eventuele in de prognosemodellen genegeerde of onderschatte factoren, die er toe zouden kunnen leiden dat de prognoses niet zullen uitkomen. De methode is zowel geschikt voor het verkrijgen van nieuwe data en het vinden van verklarende variabelen, als voor het ex ante beoordelen van de plausibiliteit van de door het ROA opgestelde prognoses. Voor het vinden van nieuwe data kan aan de verschillende bronexperts een overzicht worden gegeven van de prognoseresultaten in een eerdere periode en de feitelijke data die daaraan ten grondslag liggen. De deskundige kan dan aangeven wat daarin de tekortkomingen zijn en met behulp van welke data deze tekortkomingen zouden kunnen worden verholpen. Tegelijkertijd biedt deze methode de mogelijkheid om nieuwe verklarende variabelen te ontwikkelen. Daarnaast zouden de prognoses ad hoc kunnen worden bijgesteld door de algemeenexperts de voorlopige prognoses voor een komende periode voor te leggen en deze te vragen om mogelijke oorzaken te noemen voor het niet uitkomen van de prognoses. Met behulp van deze uitkomsten kan het ROA op basis van haar expertise van het gehele informatiesysteem, besluiten of er een nieuwe variabele aan het model moet worden toegevoegd, een ad hoc aanpassing dient plaats te vinden, of dat voor een bepaald segment informatie op een lager aggregatieniveau moet worden verstrekt.

Bron-experts kunnen het beste zo vroeg mogelijk in de prognosecyclus worden ingeschakeld. Bij voorkeur zou dit al bij het opstellen van het Evaluatierapport met betrekking tot eerdere prognoses kunnen gebeuren. Het beste moment om algemeen-experts in te schakelen is direct na het opstellen van de eerste voorlopige prognoses. Een nadeel van deze werkwijze is echter wel dat de voorlopige prognoses toegankelijk dienen te worden gemaakt voor de desbetreffende expert, waarbij deze in een breed kader gepresenteerd dienen te worden. In de praktijk zal dit er op neer komen dat er voor iedere expert een mini-rapportage moet worden gemaakt. Dit betekent dat het raadplegen van experts kostbaar en tijdrovend wordt, terwijl op voorhand onzeker is of het raadplegen van experts daadwerkelijk tot betere resultaten leidt.

Om betere prognoseresultaten te verkrijgen met behulp van de 'dialectic-methode' is het wenselijk dat 
de expert aan de volgende voorwaarden voldoet:

1. De expert moet beschiken over specifieke kennis van een bepaald arbeidsmarktsegment, bij voorkeur zowel van de vraag- als de aanbodzijde van de markt.

2. De expertise mag niet gekleurd zijn door de belangen die de deskundige heeft bij de arbeidsmarktontwikkelingen op het desbetreffende arbeidsmarktsegment. Dit geldt met name voor vertegenwoordigers van actoren op de arbeidsmarkt (bijvoorbeeld vertegenwoordigers van werkgeversorganisaties, beroepsverenigingen e.d.).

Deze beide voorwaarden gelden zowel voor de experts die de voorlopige prognoseresultaten dienen te interpreteren als voor de experts die aanvullende informatie kunnen leveren. Dit betekent dat er telkens een afweging dient te worden gemaakt met betrekking tot de relevantie van de aanwezige kennis of informatie en de 'bias' die de betreffende informatie of expertise kan bevatten. Het is in ieder geval noodzakelijk om te weten welke belangen een expert eventueel heeft, zodat zijn oordeel in dit licht beschouwd kan worden.

Gezien het grote aantal sterk uiteenlopende beroepen en opleidingen waarvoor prognoses dienen te worden opgesteld, is het, zoals gezegd, een onmogelijke zaak om bij iedere prognosecyclus voor ieder arbeidsmarktsegment een aantal externe experts in te schakelen. Dit maakt het noodzakelijk criteria te formuleren op basis waarvan de te raadplegen experts voor een bepaald arbeidsmarktsegment geselecteerd kunnen worden. Het belangrijkste criterium voor het inschakelen van externe expertise met betrekking tot een bepaald arbeidsmarktsegment is vanzelfsprekend de kwaliteit van de deskundigheid. Aandachtspunten daarbij zijn:

1. De kwaliteit van de informatie waarover de expert beschikt en de methodiek die ten grondslag ligt aan de toekomstverwachtingen voor het desbetreffende arbeidsmarktsegment.

2. De eventuele subjectiviteit van de expertise vanuit de positie die de expert op het desbetreffende segment inneemt.

In aansluiting hierop dient de vraag te worden gesteld voor welke arbeidsmarktsegmenten het het meest belangrijk is de ROA-prognoses voor te leggen aan externe deskundigen. Deze segmentkeuze zou kunnen plaatsvinden op basis van een tweetal criteria, die te zamen bepalend zijn voor de accuraatheid van de prognose, te weten:

1. de kwaliteit van de ROA-prognoses.

2. de heterogeniteit van de binnen het ROA-informatiesysteem onderscheiden beroeps- en opleidingssegmenten.

Een indicatie van de kwaliteit van de ROA-prognoses wordt gegeven in de ex post evaluatie van de eerdere ROA-prognoses van het desbetreffende arbeidsmarktsegment. Daarnaast zou de plausibiliteit van de voorlopige prognoses kunnen worden beoordeeld op basis van het algemene beeld dat men heeft van de ontwikkelingen op het desbetreffende arbeidsmarktsegment.

Ook de mate van heterogeniteit van een bepaald arbeidsmarktsegment kan een belangrijk criterium vormen voor het inschakelen van externe expertise. Bovendien zou langs deze weg mogelijk aanvullende informatie kunnen worden verkregen op basis waarmee de arbeidsmarktprognose voor het desbetreffende segment kan worden verbijzonderd. 
$\ldots \ldots$ 


\section{Aandachtspunten binnen het ROA-informatiesysteem}

\subsection{Inleiding}

Een nadere specificatie van de probleemsegmenten, waarvoor het gewenst zou zijn externe expertise in te schakelen kan, zoals aan het eind van het vorige hoofdstuk werd aangegeven, tot stand komen door vast te stellen voor welke arbeidsmarktsegmenten de ex post evaluatie van de eerdere arbeidsmarktprognoses grote verschillen liet zien tussen de verwachtingen en de uiteindelijke feitelijke ontwikkelingen op het desbetreffende arbeidsmarktsegment. Om dit goed in beeld te brengen is het wenselijk daarbij niet alleen te kijken naar de voorspelkracht van de uiteindelijke typering van de arbeidsmarktperspectieven per opleidingstype, maar ook de performance van de diverse daaraan ten grondslag liggende specifieke vraag- en aanbodprognoses in ogenschouw te nemen. Daarom zal in dit hoofdstuk achtereenvolgens op de verschillende deelprognoses naar beroep en opleiding worden ingegaan. daarbij zal zowel gekeken worden naar de beroepsklassen en opleidingstypen waarvan de prognose achteraf te optimistisch bleek te zijn geweest, als de categorieën waarvoor de prognose te ongunstig is geweest. In beide gevallen blijken de relevante verklarende variabelen immers niet, of onvoldoende, in het model te zijn opgenomen. Bij de bespreking van de verschillende deelprognoses zal telkens ook summier worden aangegeven welke verklarende factoren feitelijk ten grondslag liggen aan de desbetreffende prognoses.

Eerst zal in paragraaf 3.2 een beeld worden geschetst van de beroepsklassen waarvoor de uitbreidingsvraag en/of de vervangingsvraag in de vorig jaar geëvalueerde prognoseperiode 1985-1992 (zie Borghans, Van Eijs en De Grip, 1994) slecht is voorspeld. Daarna zal in paragraaf 3.3 achtereenvolgens worden ingegaan op de opleidingstypen met slechte prognoseresultaten voor de uitbreidingsvraag, de vervangingsvraag, de instroom van schoolverlaters en de uiteindelijke typering van de arbeidsmarktsituatie voor de schoolverlaters met de desbetreffende opleidingsachtergrond. Ten slotte worden in paragraaf 3.4 enkele concluderende opmerkingen gemaakt.

\subsection{Beroepsinformatie}

\section{Uitbreidingsvraag naar beroep}

Uit de studie van Borghans en Heijke (1993) blijkt dat bij de variabelen die gebruikt worden om de veranderingen in de beroepenstructuur te voorspellen, het grootste deel van de verklarende kracht van de trend afkomstig is. Verklarende variabelen met een inhoudelijk economisch karakter blijken slechts een klein deel van de verschuivingen in de beroepenstructuur te kunnen verklaren. Dit wordt waarschijnlijk veroorzaakt doordat vrij algemene economische variabelen voor een groep heterogene beroepen als verklarende variabele wordt opgenomen, waardoor tegengestelde effecten de voorspelkracht van de variabele teniet kunnen doen, terwijl de variabele toch van grote invloed kan zijn op een enkel beroep in deze groep. Dit leidt ertoe dat het gebruikte model slechts in geringe mate een beeld geeft van de feitelijke oorzaken van de veranderingen in de beroepenstructuur. Dit brengt het gevaar met zich mee dat de trend ten onrechte wordt geëxtrapoleerd. Het vinden van goede verklarende variabelen is daarom van groot belang. Veel mogelijke belangrijke factoren die van invloed kunnen zijn op de beroepenstructuur van de werkgelegenheid, zijn op basis van de huidige beschikbare informatie niet, of slechts zeer indirect, in kaart te brengen. Daarom is het van groot belang om nieuwe databronnen aan te boren. In de huidige opzet zijn alle verklarende variabelen van het model variabelen op bedrijfssectorniveau. Het lijkt dan ook voor de hand te liggen om in aansluiting daarop naar variabelen op beroepsklasseniveau te gaan zoeken. 
Uit Borghans, Van Eijs en De Grip (1994) blijkt dat voor de prognose van de uitbreidingsvraag naar beroep in de periode 1985-1992 er bij 20 beroepsklassen sprake bleek te zijn van een verkeerde typering van de richting van de werkgelegenheidsontwikkeling (zie tabel 1). In 14 gevallen werd er voor een beroepsklasse een (zeer) lage werkgelegenheidsgroei verwacht, terwijl er uiteindelijk sprake is geweest van een (zeer) hoge werkgelegenheidsgroei. In 6 gevallen was het omgekeerde het geval. Het is opvallend dat een aantal beroepen waarvan de uitbreidingsvraag onderschat is, sterk zijn vertegenwoordigd in de kwartaire sector, waarvoor de sectorale prognoses van het CPB ook te laag zijn uitgevallen.

Tabel 1

Prognose en realisatie uitbreidingsvraag van enkele slecht voorspelde beroepsklassen, 1985-1992

\begin{tabular}{|c|c|c|}
\hline Beroepsklasse & prognose & realisatie \\
\hline \multicolumn{3}{|l|}{ Overschatting } \\
\hline 32 Secretaresse, typist, datatypist e.d. & hoog & zeer laag \\
\hline 34 Computerapparatuur-operateurs e.d. & hoog & zeer laag \\
\hline 55 Huisbewaarders en schoonmaakpersoneel & zeer hoog & laag \\
\hline 85 Electromonteurs, -reparateurs & hoog & zeer laag \\
\hline 39 Diverse administratieve functies & hoog & laag \\
\hline 59 Diverse commerciële functies & hoog & laag \\
\hline \multicolumn{3}{|l|}{ Onderschatting } \\
\hline 15 Journalist, auteur, redacteur e.d. & zeer laag & zeer hoog \\
\hline 70 Leidinggevend produktiepersoneel & zeer laag & zeer hoog \\
\hline 12 Jurist, notaris, rechter & laag & zeer hoog \\
\hline 16 Kunstenaar, ontwerper, fotograaf, filmer & laag & zeer hoog \\
\hline 19 Sociale hulpverleners, vertalers e.d. & zeer laag & hoog \\
\hline 36 Conducteur & laag & zeer hoog \\
\hline 94 Ambachts- en industrieberoepen n.e.g. & zeer laag & hoog \\
\hline 20 Hogere leidinggevende functies bij openbaar bestuur & laag & hoog \\
\hline 31 Uitvoerend hoofdambtenaar & laag & hoog \\
\hline 33 Bankemployé, lokettisten e.d. & laag & hoog \\
\hline 54 Huishoudelijk en verzorgend personeel & laag & hoog \\
\hline 64 Visser, jager & laag & hoog \\
\hline 81 Meubelmaker en andere houtbewerkers & laag & hoog \\
\hline 98 Chauffeurs, matrozen, treinbestuurders & laag & hoog \\
\hline
\end{tabular}

Bron: ROA

\section{Vervangingsvraag naar beroep}

De prognoses van de vervangingsvraag per beroepsklasse zijn gebaseerd op de 'cohort-change-rates' van de leeftijdsopbouw van de werkzame personen in een beroepsklasse. Daarbij wordt gecorrigeerd voor de algehele conjuncturele ontwikkeling en de verwachte veranderingen in de participatiegraad. Een nadeel van deze methode is dat per cohort alleen de netto-effecten worden gemeten. Als er binnen een bepaalde leeftijdsgroep zowel personen in een beroepsklasse instromen als uitstromen, wordt alleen het netto-resultaat gemeten. Dit probleem wordt gedeeltelijk ondervangen door de werkenden in een beroepsklasse te splitsen naar leeftijd en geslacht. Daardoor zijn werkzame personen zoveel mogelijk ingedeeld in homogene groepen waarbinnen of alleen instroom, of alleen uitstroom plaatsvindt.

Voor mannen is deze oplossing waarschijnlijk voldoende nauwkeurig, omdat voor deze groep de in- en uitstroom in een bepaalde beroepsklasse op specifieke leeftijden plaatsvindt. Een uitzondering hierop vormt de groep jongeren die de eerste jaren na hun intrede op de arbeidsmarkt nogal eens van beroep veranderen. Voor vrouwen ontstaan er echter problemen als gevolg van herintrede. Als in de leeftijdscategorieën waarin sommige vrouwen herintreden, andere vrouwen de beroepsklasse verlaten zal een gedeelte van de uitstroom of een gedeelte van de instroom niet worden waargenomen. Een oplossing hiervoor zou gevonden kunnen worden in het gebruik maken van de retrospectieve vraag in 
de EBB, waarin naar de belangrijkste activiteit van het voorgaande jaar wordt gevraagd.

Binnen de huidige opzet van het informatiesysteem is het bepalen van de netto vervangingsvraag weliswaar consistent, maar indien het mogelijk wordt om de instroom in oudere leeftijdsgroepen (herintreders en personen die van beroep veranderen) in beeld te brengen, kan ook de potentiële concurrentie van deze groepen voor de schoolverlaters die zich op de arbeidsmarkt aanbieden expliciet in de analyse worden betrokken. Tenslotte is het belangrijk meer inzicht te krijgen in het gedrag van bedrijven bij uiteenlopende ontwikkelingen in de werkgelegenheid. De vraag is of bij teruglopende vraag de instroom van nieuwkomers wordt beperkt of dat oudere werknemers versneld uit het beroep zullen stromen. Verwacht kan worden dat een slechte specificatie van dit verband vooral negatieve gevolgen heeft voor de vervangingsvraagprognoses als er een omslag plaatsvindt in de werkgelegenheidsontwikkeling. Het lijkt dan ook noodzakelijk om meer informatie te verkrijgen betreffende het verloop van de uitstroomcurve.

Tabel 2

Prognose en realisatie vervangingsvraag van enkele slecht voorspelde beroepsklassen, 1985-1992

\begin{tabular}{|c|c|c|}
\hline Beroepsklasse & prognose & realisatie \\
\hline \multicolumn{3}{|l|}{ Overschatting } \\
\hline 83 Smeden, gereedschapsmakers e.d. & zeer hoog & laag \\
\hline 87 Loodgieter, pijpfitter, lasser e.d. & zeer hoog & laag \\
\hline 95 Metselaar, timmerman, e.a. bouwvakkers & zeer hoog & laag \\
\hline 98 Chauffeurs, matrozen, treinbestuurders & hoog & zeer laag \\
\hline 84 Instrumentmakers, monteurs e.d. & hoog & laag \\
\hline 93 Schilder e.d. & hoog & laag \\
\hline \multicolumn{3}{|l|}{ Onderschatting } \\
\hline 17 Musicus, dirigent, toneelspeler e.d. & zeer laag & zeer hoog \\
\hline 41 Directeur en bedrijfsleider detailhandel & zeer laag & zeer hoog \\
\hline 78 Tabakbewerker, tabakproduktenmaker & zeer laag & zeer hoog \\
\hline 86 Geluids-, beeldapparatuurbedieners & zeer laag & zeer hoog \\
\hline 02 Ingenieurs, tekenaars e.d. & laag & zeer hoog \\
\hline 04 Vliegtuig- en scheepsofficieren & laag & zeer hoog \\
\hline 05 Bioloog, biochemicus, landbouwkundige & zeer laag & hoog \\
\hline 18 Beroepssporter, trainer, sportleraar & laag & zeer hoog \\
\hline 35 Leidinggevend personeel transportbedrijf & laag & zeer hoog \\
\hline 52 Leidinggevend huishoudelijk personeel & laag & zeer hoog \\
\hline 57 Kapper, schoonheidsspecialist & laag & zeer hoog \\
\hline 60 Bedrijfsleider land- en tuinbouw & laag & zeer hoog \\
\hline 88 Goud- en zilversmeden & laag & zeer hoog \\
\hline 91 Papierwaren-, kartonagewerker & laag & zeer hoog \\
\hline 01 Schei-, natuurkundiggen e.a. technici & laag & hoog \\
\hline 09 Econoom & laag & hoog \\
\hline 14 Theoloog, dominee, pastor e.d. & laag & hoog \\
\hline 37 Postsorteerder, postbesteller e.d. & laag & hoog \\
\hline 42 Zelfstandig groothandelaar, tussenhandelaar & laag & hoog \\
\hline 46 Vertegenwoordiger & laag & hoog \\
\hline 61 Zelfstandige land- en tuinbouwers & laag & hoog \\
\hline 85 Electromonteurs, -reparateurs & laag & hoog \\
\hline 97 Laders, lossers, inpakkers e.d. & laag & hoog \\
\hline
\end{tabular}

Bron: ROA

Uit tabel 2 blijkt dat in 29 van de 79 gevallen bij de evaluatie van het informatiesysteem een kwalitatieve typering van de vervangingsvraag werd gevonden die in de verkeerde richting wees. In 6 gevallen werd een hoge of zeer hoge typering gegeven, terwijl deze laag of zeer laag had moeten zijn. In 23 gevallen was het omgekeerde het geval.

\section{Baanopeningen naar beroepsklasse}

De mogelijkheden voor nieuwkomers op de arbeidsmarkt om werk te vinden binnen een bepaalde 
beroepsklasse, worden bepaald door de hoeveelheid baanopeningen. Dit is de eindinformatie die gegenereerd wordt met betrekking tot de toekomstige arbeidsmarktontwikkelingen naar beroepsklasse. Baanopeningen zijn het resultaat van het optellen van de vervangings- en de uitbreidingsvraag. Voorspelfouten zijn dus een rechtstreeks gevolg van één van beide of beide componenten. Daarbij bestaat echter ook de mogelijkheid dat tegengestelde voorspelfouten bij de uitbreidings- en de vervangingsvraagprognoses elkaar compenseren.

Tabel 3 geeft een overzicht van alle beroepsklassen waarvan de realisatie sterk afweek van de prognose. In totaal werd er voor 12 van de 79 beroepsklassen een relatief laag of zeer laag aantal baanopeningen voorspeld, terwijl deze beroepsklassen achteraf gezien hoog of zeer hoog als typering hadden moeten krijgen. Bij 12 andere beroepen het omgekeerde geconstateerd. Al met al is bij $30 \%$ van de beroepsklassen een verkeerde typering gegeven.

Tabel 3

Prognose en realisatie baanopeningen van enkele slecht voorspelde beroepsklassen, 1985-1992

\begin{tabular}{|c|c|c|}
\hline Beroepsklasse & prognose & realisatie \\
\hline \multicolumn{3}{|l|}{ Overschatting } \\
\hline 32 Secretaresse, typist, datatypist e.d. & zeer hoog & laag \\
\hline 34 Computerapparatuur-operateurs e.d. & zeer hoog & laag \\
\hline 43 Zelfstandige winkeliers & hoog & zeer laag \\
\hline 51 Zelfstandig hotel-, restaurant-, caféhouder & hoog & zeer laag \\
\hline 55 Huisbewaarders en schoonmaakpersoneel & zeer hoog & laag \\
\hline 75 Spinners, wevers e.d. & zeer hoog & laag \\
\hline 39 Diverse administratieve functies & hoog & laag \\
\hline 63 Boswachter en bosarbeider & hoog & laag \\
\hline 79 Kleermakers, stoffeerders e.d. & hoog & laag \\
\hline 85 Electromonteurs, -reparateurs & hoog & laag \\
\hline 87 Loodgieter, pijpfitter, lasser e.d. & hoog & laag \\
\hline 95 Metselaar, timmerman, e.a. bouwvakkers & hoog & laag \\
\hline \multicolumn{3}{|l|}{ Onderschatting } \\
\hline 15 Journalist, auteur, redacteur e.d. & zeer laag & zeer hoog \\
\hline 70 Leidinggevend produktiepersoneel & zeer laag & zeer hoog \\
\hline 12 Jurist, notaris, rechter & laag & zeer hoog \\
\hline 16 Kunstenaar, ontwerper, fotograaf, filmer & laag & zeer hoog \\
\hline 17 Musicus, dirigent, toneelspeler e.d. & zeer laag & hoog \\
\hline 19 Sociale hulpverleners, vertalers e.d. & zeer laag & hoog \\
\hline 41 Directeur en bedrijfsleider detailhandel & laag & zeer hoog \\
\hline 52 Leidinggevend huishoudelijk personeel & zeer laag & hoog \\
\hline 60 Bedrijfsleider land- en tuinbouw & zeer laag & hoog \\
\hline 57 Kapper, schoonheidsspecialist & laag & hoog \\
\hline 64 Visser, jager & laag & hoog \\
\hline 90 Rubber-, plasticproduktenmaker & laag & hoog \\
\hline
\end{tabular}

Bron: ROA

\subsection{Opleidingsinformatie}

\section{Uitbreidingsvraag naar opleidingstype}

Evenals bij de uitbreidingsvraag naar beroepsklasse, geldt voor het prognosemodel voor de uitbreidingsvraag naar opleidingstype dat het erg moeilijk is geschikte verklarende variabelen te vinden. Het is doorgaans niet zo dat er slechts één bepaalde opleiding geschikt is voor een bepaald beroep. De Grip en Heijke (1991) laten zien dat het belangrijk is te onderkennen dat er voor het uitoefenen van een bepaald beroep meerdere opleidingstypen in aanmerking komen. De vraag naar arbeid per beroepsklasse kan in het algemeen dan ook door mensen met verschillende opleidingsachtergronden worden opgevuld. Aan de andere kant is er ook vanuit verschillende beroepsklassen vraag naar een bepaald opleidingstype. De schaarsteverhoudingen op de arbeidsmarkt bepalen ook in hoeverre 
arbeidskrachten met een bepaalde opleidingsachtergrond uitwijken naar banen die onder het niveau liggen van de gevolgde opleiding. Borghans, Van Eijs en De Grip (1994) wijzen er op dat dit betekent dat de voorspelde uitbreidingsvraag daardoor niet gelijk hoeft te zijn aan de feitelijke toekomstige werkgelegenheid per opleidingstype. Borghans c.s. trekken daaruit de conclusie dat het niet zinvol is deze uitbreidingsvraagprognoses empirisch te evalueren. Derhalve is het vooralsnog niet mogelijk een beeld te geven voor welke opleidingstypen de uitbreidingsvraagprognoses een slechte voorspelkracht hebben.

\section{Vervangingsvraag naar opleidingstype}

Bij de vervangingsvraag per opleidingstype spelen vergelijkbare problemen een rol als bij de vervangingsvraag per beroepsklasse. Als de prognoses niet meer eenvoudigweg afhangen van het aantal personen boven een bepaalde leeftijd, zoals bij de prognoses voor de periode 1985-1992 nog het geval was, maar worden bepaald op basis van historische uitstroomcijfers, zoals in de latere prognoses ook is gedaan, spelen de eerder genoemde meetproblemen weer een rol. Bovendien zal verder onderzocht dienen te worden wat het verband is tussen de (ex ante) uitbreidingsvraag en de uitstroom.

Tabel 4 geeft een overzicht van opleidingstypen waarvoor de prognose en realisatie van de vervangingsvraag sterk van elkaar afwijken. Voor 19 van de 53 opleidingstypen bleek de prognose sterk af te wijken van de realisatie. In alle gevallen werd een lage tot zeer lage vervangingsvraag verwacht terwijl de realisatie in feite hoog tot zeer hoog was.

Tabel 4

Prognose en realisatie vervangingsvraag van enkele slecht voorspelde opleidingstypen, 1985-1992

\begin{tabular}{lll}
\hline & & \\
Opleidingstype & prognose & \\
\hline & & realisatie \\
Onderschatting & zeer laag & zeer hoog \\
652 Farmacie, Medische biologie e.d. & laag & zeer hoog \\
351 Lager medisch en paramedisch onderwijs & laag & zeer hoog \\
391 Opl. bedrijfsbeveiliging en -bewaking & laag & zeer hoog \\
406 Opleiding rij-instructeur, sportleider & laag & zeer hoog \\
452 Mid. laboratorium onderwijs (medisch) & laag & zeer hoog \\
486 Modetekenen e.d. & laag & zeer hoog \\
511 Tolk- en vertalersopleidingen & laag & zeer hoog \\
516 Opleiding pastoraal werk e.d. & laag & zeer hoog \\
521 Hoger agrarisch onderwijs & laag & zeer hoog \\
552 Hoger laboratorium onderwijs (medisch) & laag & zeer hoog \\
554 Opleiding diëtiek e.d. & laag & zeer hoog \\
566 HEAO, juridisch en bestuurlijke richting & laag & zeer hoog \\
606 Universitaire lerarenopleiding, MO-B & laag & laag \\
616 Theologie (universitair) & laag & zeer hoog \\
621 Agrarische wetenschappen & laag & laag \\
636 Technische wetenschappen & laag & zeer hoog \\
662 Bedriffs. (ir), econometrie en actuariaat & & zeer hoog \\
686 Kunstwetenschappen & hoog \\
401 Havo en WWO &
\end{tabular}

\section{Bron: ROA}

\section{Aanbod van schoolverlaters.}

Voor het ROA-informatiesysteem worden naast de ramingen voor het reguliere voltijdse onderwijs (Referentieraming van het Ministerie van Onderwijs, Cultuur en Wetenschappen) nog talloze andere informatiebronnen gehanteerd voor de niet-reguliere opleidingen. Dit betreft onder andere gegevens over het erkend schriftelijk onderwijs, bedrijfsopleidingen, landbouwonderwijs, defensie-onderwijs en scholingsmaatregelen van de Arbeidsvoorzieningsorganisatie. Ook voor het leerlingwezen moeten 
verschillende bronnen worden geraadpleegd. De informatie in deze bronnen is vaak slecht toegankelijk, onbetrouwbaar en geclassificeerd op een wijze die niet binnen de CBS-classificaties past. Bovendien bestaat het gevaar bij deze opleidingen dat er dubbeltellingen gaan optreden doordat in onvoldoende mate kan worden vastgesteld welke de hoogst voltooide opleiding is geweest. Een expert op het gebied van het niet-reguliere onderwijs die beschikt over het CBS consistente data, zou dan ook een grote bijdrage kunnen leveren aan de verbetering van de kwaliteit van het ROA-informatiesysteem.

De aanpak van de aanbodprognoses tot 1992 heeft het onmogelijk gemaakt om deze te evalueren. Bij de aanpak voor de prognose tot 1992 werden de SKILL-prognoses van OCW rechtstreeks vertaald naar prognoses van de instroom van schoolverlaters per ROA-opleidingstype voor de prognosejaren 19851992. Deze methodiek levert onmiddellijk prognoses op zonder dat het nodig is eerst historische data te reconstrueren. Daardoor zijn er geen 'feitelijke' historische data beschikbaar op basis waarvan de aanbodprognoses voor de periode 1985-1992 kunnen worden geëvalueerd. Om tot geschikte evaluatiecijfers te komen op het aggregatieniveau dat in het informatiesysteem wordt gehanteerd, zouden er bovendien reconstructies van de data moeten plaatsvinden die vergelijkbaar zijn met de bewerkingen die in de prognoses hebben plaatsgevonden. Hierdoor kunnen deze aanpassingen zelf niet geëvalueerd worden.

\section{Arbeidsmarktperspectief}

Op basis van de bovengenoemde vraag- en aanbodprognoses wordt in het informatiesysteem onderwijs-arbeidsmarkt het arbeidsmarktperspectief per opleidingstype in beeld gebracht. Bij de door Borghans, Van Eijs en De Grip (1994) geëvalueerde prognoses was dit perspectief nog gebaseerd op de AMl: het quotiënt van aanbod en vraag van nieuwkomers op de arbeidsmarkt. Borghans c.s. hebben onderzocht of er een relatie bestaat tussen de AMI en de arbeidsmarktpositie van opleidingstypen. Uit de evaluatie blijkt dat de AMI redelijk goed voldoet. Bij 13 van de 42 opleidingstypen komt de kwalitatieve typering precies overeen met de realisatie. Dit is $30 \%$ van alle opleidingstypen. Als hierbij wordt meegerekend, de typeringen die slechts één categorie naast de gerealiseerde typering zijn voorspeld, komt het percentage uit op $67 \%$. Tabel 5 laat zien dat er vrijwel geen opleidingstypen zijn waarbij de prognose en realisatie in een tegengestelde richting wijzen. Alleen voor het zeer heterogene en moeilijk van andere opleidingstypen af te bakenen opleidingstype universitaire lerarenopleiding MO-B werd een slecht perspectief voorspeld terwijl de realisatie redelijk was.

Tabel 4

Prognose en realisatie arbeidsmarktperspectief van enkele slecht voorspelde opleidingstypen, 1985-1992

\begin{tabular}{lcc}
\hline Opleidingstype & prognose & realisatie \\
\hline $\begin{array}{l}\text { Onderschatting } \\
606 \text { Universitaire Lerarenopleiding, MO-B }\end{array}$ & slecht & redelijk
\end{tabular}

Bron: ROA

\subsection{Conclusie}

Uit het bovenstaande blijkt dat de samenvattende prognoses van het arbeidsmarktperspectief naar opleidingstype een grotere voorspelkracht hebben dan de prognoses naar beroepsklasse ${ }^{3}$. Kennelijk werken niet alle prognosefouten bij beroepsklassen door bij de voorspellingen van de opleidingstypen

3. Dit werd ook al geconstateerd in De Grip, Heijke en Berendsen (1991). 
en heeft ook de relatief goed voorspelbare aanbodcomponent een positieve invloed op de prognoseresultaten. De voorspelfouten bij de beroepsklassen en opleidingstypen vertonen een brede spreiding over de verschillende economische sectoren, zodat er geen sector naar voren springt, waar de noodzaak tot het inschakelen van externe expertise het meest evident is. Gezien het relatief groot aantal voorspelfouten in de vraagprognoses per beroepsklasse kan echter wel geconcludeerd worden dat het goed zou zijn om vooral voor deze prognose-onderdelen gebruik te maken van externe deskundigheid. Vanwege het verkennende karakter van dit rapport is het, ook gezien de spreiding van de voorspelfouten over de beroepsklassen, wenselijk om in eerste instantie een zo breed mogelijk deel van de arbeidsmarkt in beschouwing te nemen. 
$\ldots \ldots$ 


\section{Deelmarktexpertise}

\subsection{Inventarisatie expertisebronnen}

Een groot aantal instellingen beschikt op enigerwijze wel over data of expertise met betrekking tot bepaalde beroepsgroepen, opleidingstypen en/of sectorontwikkelingen. Bijlage A geeft een overzicht van de resultaten van een eerste inventarisatie van mogelijke expertise-bronnen. Het gaat hierbij veelal om expertise met betrekking tot een bepaalde beroepsgroep, een opleidingstype of een bepaalde branche. In weinig gevallen zal de informatie betrekking hebben op de volledige arbeidsmarkt voor de desbetreffende beroepsklasse of het desbetreffende opleidingstype.

De organisaties die beschikken over segmentspecifieke data-/expertise-bronnen zouden in een zestal groepen kunnen worden ingedeeld, te weten:

- branche-specifieke onderzoeksinstellingen;

- werkgeversverenigingen;

- branche-specifieke onderwijsorganen;

- beroepsverenigingen;

- overheidsorganen;

- particuliere onderwijsinstellingen.

De eerste groep bestaat uit de aan een branche of sector gelieerde onderzoeksinstellingen, zoals het Sociaal Cultureel Planbureau (SCP, kwartaire sector), het Nationaal Ziekenhuisinstituut (NZi, ziekenhuizen), het Nederlands Instituut voor Onderzoek van de Eerstelijnsgezondheidszorg (NIVEL, extramurale sector), het Economisch Instituut voor de Bouwnijverheid (EIB, bouwsector), het Economisch Instituut voor het Midden- en kleinbedrijf (EIM, midden- en kleinbedrijf), het Landbouw Economisch Instituut (LEI) en STOAS (landbouw). Deze organisaties houden zich bezig met segmentspecifiek arbeidsmarktonderzoek. Dit betekent vaak ook dat deze instellingen op een systematische manier data verzamelen en soms ook zelf arbeidsmarktprognoses maken.

De tweede groep die kan worden onderscheiden is die van de werkgeversverenigingen. Naast de overkoepelende organisaties als het Verbond van Nederlandse Ondernemingen (VNO), de Raad van de Centrale Ondernemingsorganisaties (RCO), het Nederlands Christelijk Werkgeversverbond (NCW) en het Koninklijk Nederlands Ondernermersverbond (KNOV), zijn dit de branche-organisaties (zie ook Bijlage A). Dit zijn organisaties die als representant van een groot aantal leden uitdrukkelijk de werkgeversbelangen vanuit een bepaalde bedrijfssector richting beleidsvorming behartigen waarbij vanzelfsprekend de arbeidsmarktproblematiek doorgaans een grote rol speelt. Dit wil echter niet zeggen dat er systematisch data worden verzameld. Wel is er bij deze organisaties zeer veel praktische kennis aanwezig met betrekking tot de actuele arbeidsmarktsituatie en de ontwikkelingen die zich binnen de desbetreffende sector voordoen. Door hun gerichtheid op een bepaalde bedrijfssector is de expertise vanuit deze organisaties met betrekking tot de beroepsklassen en opleidingstypen die in meerdere sectoren werkzaam zijn, doorgaans beperkt tot het sectorspecifieke deelsegment.

De derde groep die kan worden onderscheiden betreft de verschillende branche-gelieerde onderwijsorganen die, meestal in het kader van het leerlingwezen, de vakopleidingen verzorgen. Dit zijn organisaties als het SVEB (Stichting voor Vakopleidingen en Examens in het Bakkersbedrijf), SOM (opleidingen metaal), VOCar (Stichting Opleidingen in het Carrosseriebedrijf), VOCON (Stichting Vakopleiding Confectie-industrie), SVGB (Stichting Vakopleiding Gezondheidstechnische Beroepen), Onderwijscentrum Horeca, etc. Deze organisaties zouden normaliter een indruk moeten kunnen geven 
van de ontwikkelingen in het onder hen ressorterende onderwijs en zijn vanuit dit oogpunt ook erg interessant.

De vierde groep die kan worden onderscheiden zijn de beroepsverenigingen en de organisaties die sterk gelieerd zijn aan één bepaald opleidingstype. Voorbeelden hiervan zijn het NILI (Nederlands Instituut voor Landbouwkundig Ingenieurs), KNCV (Koninklijke Nederlandse Chemische Vereniging), NIBI (Nederlands Instituut van Biologen), NIP (Nederlands Instituut van Psychologen), NIVRA (Nederlands Instituut van Registeraccountants), NIRIA (Nederlandse Ingenieursvereniging), het KIVI (Koninklijk Instituut van Ingenieurs), etc. Gegevens en expertise binnen deze organisaties variëren van ledenbestanden tot korte-termijn-prognoses.

De vijfde groep die kan worden onderscheiden zijn de overheidsorganen. De overheidsorganen beschikken op een tweetal wijzen over relevante deskundigheid. Aan de ene kant bouwen zij deskundigheid op als opdrachtgever voor arbeidsmarktonderzoek (bijvoorbeeld voor de lerarenprognoses van het IVA), aan de andere kant beschikken zij ook over deskundigheid door zelf data te verzamelen (bijvoorbeeld het verzamelen van arbeidsmarktinformatie met betrekking tot de overheidssectoren door het Ministerie van Binnenlandse Zaken).

Ten slotte zijn er nog organisaties die zich specifiek met het particuliere niet-reguliere onderwijs bezighouden. Hierbij kan gedacht worden aan organisaties als de PBNA, SVE (Stichting Landelijk Studiecentrum voor Volwasseneneducatie) en de LOI. Deze organisaties beschikken over data met betrekking tot een groot aantal niet-reguliere opleidingen.

Zoals gezegd is het periodiek raadplegen van alle mogelijke bronnen van eventuele data en/of expertise een onhaalbare opgave. Bovendien is het twijfelachtig of de baten van het benaderen van een groot aantal organisaties wel opwegen tegen de kosten. Daarom is besloten om in eerste instantie te verkennen in hoeverre enkele organisaties, waarvan op voorhand zou mogen worden verwacht dat deze over bruikbare data of expertise beschikken, een rol zouden kunnen vervullen bij de totstandkoming van de ROA-prognoses. Daarbij zouden de organisaties geselecteerd dienen te worden op basis van de kwaliteit van hun expertise.

De in hoofdstuk 2 gedefinieerde kwaliteit van deskundigheid kan daarbij operationeel worden gemaakt door middel van een elftal overwegingen die bij de keuze van de te benaderen organisaties een belangrijke rol kunnen spelen:

1. Beschikt de organisatie over relevante data?

2. Dekt de beschikbare data een volledig beroeps- en/of opleidingssegment?

3. Beschikt de organisatie over relevante data op een lager aggregatie niveau?

4. Zijn de aanwezige data te koppelen aan CBS-classificaties?

5. Is de organisatie bereid om data af te staan ten behoeve van ROA-informatie systeem?

6. Heeft de organisatie zowel kennis van de vraag- als de aanbodzijde van het arbeidsmarktsegment?

7. Is er binnen de organisatie expertise aanwezig die kan bijdragen tot de ontwikkeling van nieuwe verklarende variabelen?

8. Is inzicht aanwezig in de te verwachten toekomstige ontwikkelingen?

9. Kan de aanwezige expertise leiden tot een bijstelling van de modeluitkomsten?

10. Beschikt de organisatie over eigen prognoses?

11. In hoeverre is de expertise niet gekleurd of kan de expertise eenvoudig objectief gemaakt worden? 
Op basis van deze aandachtspunten mag verwacht worden dat vooral de branche-specifieke onderzoeksinstellingen een waardevolle bron van externe expertise zouden kunnen vormen ${ }^{4}$. Naast de kwaliteit van de deskundigheid, is de heterogeniteit van de binnen het ROA-informatiesysteem onderscheiden beroepsklassen en opleidingstypen richtinggevend geweest bij de keuze van de in dit verkennende onderzoek te benaderen organisaties. Dit heterogeniteitscriterium wijst vooral in de richting van de diverse specifiek op de kwartaire sector gerichte beroepsopleidingen, omdat hier veel sprake is van onderling sterk afgebakende vakdeelmarkten. Daarnaast zijn ook de huidige technische opleidingstypen erg breed gedefinieerd. Tenslotte was het, zoals gezegd, in eerste instantie de bedoeling om het inschakelen van expertise vooral te richten op de beroepsklassen en opleidingstypen waarvan de prognoses sterk afweken van de realisatie. In hoofdstuk 3 kwam echter naar voren dat de voorspelfouten binnen het informatiesysteem onderwijs-arbeidsmarkt voor de periode 1985-1992 zich niet concentreren in één bepaald segment van de arbeidsmarkt. Dit maakt het wenselijk om, op basis van de te voeren gesprekken, een zo breed mogelijk deel van de arbeidsmarkt af te dekken.

\subsection{Gesprekken met deskundigen}

Mede in het licht van de kwaliteit van de eerdere prognoseresultaten, maar vooral op basis van de heterogeniteit van de binnen het ROA-informatiesysteem onderscheiden arbeidsmarktsegmenten, is het, zoals gezegd, vooral bij de kwartaire beroepen en opleidingstypen wenselijk om over meer segmentspecifieke informatie te beschikken. Daarbij is het niet de bedoeling om de sectorprognoses zoals deze door het CPB zijn opgesteld te gaan aanpassen, aangezien dit tot de competentie van het CPB gerekend kan worden. Wel zouden de beroepen en opleidingen die toegang geven tot de kwartaire sector nader geanalyseerd kunnen worden. Uit dien hoofde leek het dan ook aannemelijk om een gesprek met het Sociaal Cultureel Planbureau te voeren. Temeer daar het SCP zelf prognoses maakt voor de kwartaire sector die naast de CPB-prognoses voor deze sector gelegd kunnen worden. Tevens zou het SCP kunnen bijdragen in het vinden van voor de kwartaire sector specifieke verklarende variabelen.

Het Sociaal en Cultureel Planbureau (SCP) houdt zich bezig met het beschrijven van de huidige situatie en de te verwachten ontwikkelingen op sociaal en cultureel terrein in Nederland. Tevens dient het SCP bij te dragen tot verantwoorde keuzen van doeleinden en middelen in het sociale en culturele beleid en het ontwikkelen van alternatieven. Tenslotte heeft het SCP een taak bij de beoordeling van het gevoerde beleid, speciaal waar het interdepartementale vraagstukken betreft. Het bureau omvat drie onderzoeksafdelingen waarvan er één gericht is op politicologische en bestuurskundige onderwerpen en één op sociaal-economische onderwerpen. De derde afdeling omvat sectorspecialisten op de diverse deelterreinen van de kwartaire sector (zorg, onderwijs, arbeid en sociale zekerheid e.d.). Permanente taken zijn het vervaardigen van het Sociaal en Cultureel Rapport, de Sociale en Culturele Verkenningen en het uitbrengen van adviezen aangaande de allocatie van middelen in de kwartaire sector.

In een gesprek met de heer Kuhry van het SCP kwam naar voren dat het SCP in het verleden diverse malen heeft gerapporteerd over vraag en aanbod van personeel in de kwartaire sector, over de perspectieven van enkele beroepsgroepen in die sector en over discrepanties op de arbeidsmarkt naar opleidingsniveau. Op dit moment houdt het SCP zich niet bezig met arbeidsmarktperspectieven naar

4. Ook de diverse landelijke organen van het leerlingwezen beschikken over een schat aan informatie over de leerlingenontwikkelingen van de door hen verzorgde opleidingen. Door een specifiek op het leerlingwezen toegespitste prognose-studie heeft het ROA recentelijk reeds een goed beeld gekregen van de bij deze organisaties beschikbare data (zie De Grip, Berendsen, Borghans en Dekker, 1993) 
studierichting of naar specifieke beroepsgroep, maar wel met meer algemene vraagstukken (zoals overscholing en de problematiek van de 'onderkant' van de arbeidsmarkt). De in dit verband gebruikte ramingen worden veelal ontleend aan andere instanties zoals het CPB, IVA, OSA en ROA. Bij ramingen van het gebruik en de kosten van kwartaire diensten spelen personeelsgegevens een ondergeschikte rol. Ook betreft het hier ramingen die gericht zijn op de vraag naar diensten, waarbij beleidseffecten zoveel mogelijk worden geëlimineerd. Derhalve zijn in dit kader op te stellen personeelsramingen niet zonder meer geschikt voor arbeidsmarktprognoses.

Binnen het SCP zijn enkele interessante ontwikkelingen waar te nemen. Zo is het SCP samen met het CPB en het RIVM bezig een vraag-aanbodmodel voor de zorgsector te ontwikkelen. Een eerste rapportage hierover is voorzien in 1996. Ook vindt er momenteel binnen het SCP een evaluatie plaats van de voorspellende waarde van onderwijsramingen. Hieruit komt onder andere naar voren, dat de voorspelkracht van deze prognoses, zeker op de lange termijn, slechts zeer beperkt is. Een gedetailleerde publikatie over dit onderwerp zal in 1995 verschijnen.

Een tweede gesprek is gevoerd met de heer Groenewegen, hoofd onderzoeksafdeling I, en de heer Hingstman, projectleider themagebied 'volume en functieaanbod', van het Nederlands Instituut voor Onderzoek van de Eerstelijnsgezondheidszorg (NIVEL). Het NIVEL beschikt over enkele registratiebestanden met betrekking tot huisartsen, verloskundigen en fysiotherapeuten (werkzaam in de eerstelijnszorg). Daarnaast publiceert het NIVEL behoefteramingen voor specifieke beroepsgroepen, waaronder ook de medisch specialisten. In deze studies wordt naast de behoefteraming ook een aanbodprognose opgesteld, waarna er een vraag-aanbodconfrontatie plaatsvindt. Doorgaans gaat het daarbij om lange-termijn-scenario-studies. Zo hebben de vorig jaar verschenen behoefteraming voor ergotherapeuten (Harmsen c.s., 1993) en gynaecologen/obstetrici (Hingstman c.s., 1993) betrekking op het jaar 2005. Vanuit NIVEL bestaat in principe belangstelling voor samenwerking met het ROA, zij het dat daarbij wel uitdrukkelijk gedacht wordt in termen van gezamenlijk uit te voeren onderzoeksprojecten.

Een derde gesprek is gevoerd met mevrouw Van den Bandt-Stel van het Verbond van Nederlandse Ondernemingen (VNO). De keuze voor het VNO was met name gebaseerd op de rol die deze organisatie vervult als overkoepelend orgaan van een groot aantal werkgeversverenigingen. De verwachting was dat deze organisatie mogelijk een 'overall' beeld zou kunnen samenstellen van de bestaande expertise op de verschillende arbeidsmarktsegmenten en over informatie zou kunnen beschikken over werkgeversverenigingen die zich actief met onderzoek bezig houden.

Het VNO is de grootste centrale ondernemingsorganisatie in Nederland. In totaal zijn ruim 100 brancheorganisaties uit vrijwel alle sectoren van de economie aangesloten. Deze branche-organisaties zijn representatief voor ruim 25.000 ondernemingen. Het VNO heeft ten doel de algemene economische en sociale belangen te behartigen van in Nederland werkzame ondernemingen op regionaal, nationaal en internationaal gebied. Het VNO tracht een intermediair te zijn met betrekking tot informatiestromen van haar leden naar de politiek en van de politiek naar haar leden. Alle centrale werkgeversorganisaties werken samen in de Raad van de Centrale Ondernemingsorganisatie (RCO). Mevr. Van den Bandt-Stel houdt zich binnen het RCO bezig met onderwijs en arbeidsmarkt. Uit dien hoofde is zij betrokken bij de overkoepelende Onderwijscommissie en de twee hieraan verbonden werkgroepen Hoger Onderwijs en Middelbaar Onderwijs en Leerlingwezen.

Uit het gesprek met mevr. Van den Bandt-Stel - die ook het secretariaat voert voor de RCO-werkgroep MBO en leerlingwezen - kwam naar voren dat het VNO/RCO zelf niet beschikt over bepaalde segmentspecifieke databronnen. De data die voor de beleidsvorming worden gebruikt zijn veelal 
afkomstig van instellingen zoals het CBS en het ROA. Er zijn waarschijnlijk wel data aanwezig bij de aangesloten brancheverenigingen. Zo doet de FME regelmatig onderzoek onder haar leden, en ook de BOVAG heeft een werkgroep heeft die zich met toekomstige ontwikkelingen bezighoudt. Echter, het mag niet verwacht worden dat de brancheverenigingen erg toeschietelijk zullen zijn in het vrijgeven van niet-gepubliceerde data. De beste methode om aan bepaalde informatie te komen is door aan de hand van gerichte vragen in gesprek te gaan met vertegenwoordigers van de desbetreffende brancheorganisaties.

Mevr. Van den Bandt-Stel verwacht wel dat de leden van de verschillende werkgroepen van de RCOOnderwijscommissie een klankbordfunctie zouden kunnen vervullen voor de ROA-prognoses. Niet zozeer met betrekking tot de gebruikte data, maar wel met betrekking tot bepaalde segmentspecifieke te verwachten ontwikkelingen of incidenten. Als voorbeeld van dit laatste noemt zij de $\mathrm{KWV}$-ers die op korte termijn de landmacht zullen verlaten. Deze groep is veelal laag opgeleid en zou wellicht de door het ROA verwachte leerlingtekort in het leerlingwezen de komende tijd goed kunnen opvangen. Ook constateert zij dat er weer meer aandacht binnen de individuele bedrijven komt voor de arbeidsmarktproblematiek nu er opnieuw op sommige plekken tekorten gaan ontstaan aan een bepaald soort opgeleiden.

Een ander voorbeeld heeft betrekking op de veranderende personeelsopbouw binnen bedrijven. Er kan steeds vaker een driedeling binnen bedrijven worden waargenomen. $\mathrm{Er}$ is een bovenlaag van hoger opgeleiden met vaste contracten en zeer lange werktijden, omdat deze groep onmisbaar is voor het bedrijf. Daaromheen zit een laag hoge en middelbaar opgeleiden met vaste contracten en min of meer vaste werktijden. Vervolgens zit daar weer een zeer grote laag van hoger, maar ook middelbaar en lager, opgeleiden met tijdelijke contracten omheen.

Mevr. Van den Bandt-Stel ziet een tweetal mogelijkheden om de contacten met de leden van de onderwijswerkgroepen te realiseren.

1. Branche-organisaties kunnen individueel door het ROA benaderd worden.

2. Het is mogelijk bepaalde problemen in breder verband, vanuit het RCO georganiseerd, te bespreken met enkele mensen uit de verschillende werkgroepen.

De vierde organisatie waarmee een verkennend gesprek is gevoerd, is het STOAS. Het STOAS is een instituut dat zich intensief bezig houdt met de aansluiting tussen onderwijs en arbeidsmarkt in het agrarisch onderwijs. Van de zijde van het STOAS is in het verleden nogal eens kritiek geuit op de classificaties voor de agrarische beroepen en opleidingen zoals die in het ROA-informatiesysteem worden gebruikt. Het lijkt vanuit dit oogpunt dan ook interessant om te bekijken of dit het STOAS mogelijkheden en argumenten kan aanbieden om tot aanpassing van de classificaties voor de agrarische beroepen en opleidingen te komen.

Van origine is het STOAS de lerarenopleiding voor het landbouwonderwijs. Sinds twee jaar is aan het STOAS het Bureau arbeidsmarktonderzoek toegevoegd. Het onderzoek van het bureau arbeidsmarktonderzoek is gericht op het verzamelen van informatie waarmee landbouwonderwijsbeleid ondersteund en gestuurd kan worden, waardoor de aansluiting tussen agrarisch onderwijs en scholing en arbeidsmarkt verbeterd kan worden. De belangrijkste informatiebronnen van het STOAS zijn het loopbaanonderzoek en het bedrijyenonderzoek.

Vooral het loopbaanonderzoek bevat interessante gegevens. In het loopbaanonderzoek worden loopbanen van afgestudeerden op korte en lange termijn gevolgd. Over de arbeidsmarktpositie van 
afgestudeerden aan de Landbouw universiteit is het meest uitgebreide bestand beschikbaar. Het bestand volgt door middel van een 5 -jaarlijkse meting alle afgestudeerden tot hun pensioen. Voor het Hoger Agrarisch Onderwijs beschikt STOAS over een longitudinale analyse over een periode van ongeveer 15 jaar. Voor het Middelbaar Agrarisch Onderwijs wordt in 1995 de eerste follow-up gehouden van de in 1992 gehouden enquête. Uit de loopbaanonderzoeken blijkt dat de beroepenspreiding onder afgestudeerden erg groot is. Ook valt het op dat de arbeidsmarktperspectieven erg divers zijn tussen de verschillende afstudeerrichtingen. Vanaf 1995 worden de follow-up onderzoeken om de drie jaar gehouden.

Het STOAS signaleert een aantal problemen met betrekking tot de prognoses van het ROA:

- Veel afgestudeerden van de Landbouwuniversiteit komen buiten de sector landbouw terecht, terwijl het CBS deze afgestudeerden pas in een andere sector signaleert als er een voldoende groot aantal in de sector werkzaam zijn. Op een groep van ongeveer 20.000 is dit erg moeilijk. Dit kan leiden tot onderschatting van de daadwerkelijke vraag.

- De associatie van het opleidingstype WO agrarisch met de Landbouw Universiteit Wageningen als geheel.

- Het STOAS denkt dat in het ROA-informatiesysteem de confrontatie tussen vraag een aanbod van WO agrarisch niet juist gemaakt is. De inschatting van het STOAS is dat de vraag betrekking heeft op een deel van de studierichtingen van de Landbouwuniversiteit, maar dat bijna de volledige uitstroom uit de Landbouw Universiteit Wageningen als het aanbod voor dit opleidingstype is opgenomen, en niet alleen de agrarische opleidingen.

Het STOAS biedt het ROA aan om gebruik te kunnen maken van de meer gedetailleerde uitstroomgegevens. Ten slotte zou het volgens STOAS interessant zijn om te kijken of uitstroom en bestemming in het agrarisch onderwijs zoals deze door STOAS worden verzameld, overeenkomen met uitstroom en bestemming van agrarisch opgeleiden zoals deze door het CBS zijn verzameld en door het ROA worden gebruikt.

Een vijfde gesprek was gepland met het Economisch Instituut voor het Bouwbedrijf (ElB). Van dit instituut is bekend dat zij over een grote hoeveelheid data beschikken met betrekking tot het gehele segment. Er zijn mogelijkheden om gegevens op een lager aggregatieniveau te verkrijgen. Het instituut doet zelf onderzoek en heeft in het verleden zelf middellange-termijn prognoses gemaakt (zie bijvoorbeeld Kranenborg en Stroo, 1993). Dit betekent dat dit instituut zowel een bijdrage kan leveren in het verkrijgen van relevante data, als in het vinden van verklarende variabelen, als in het ex post bijstellen van de modeluitkomsten.

Nadat een eerste afspraak was afgezegd werd er vanuit het EIB aangegeven dat het niet zinvol zou zijn om een gesprek te voeren, omdat men op directieniveau niet bereid was meer informatie ter beschikking te stellen dan in de eigen rapporten beschreven staat. Deze opstelling valt zeer te betreuren, daar de publikaties van het EIB aangeven dat er een schat aan informatie en kennis met de betrekking tot de arbeidsmarkt in de bouw aanwezig is. Het rapport Het arbeidsbestand in de bouwnijverheid in 1992 toont aan dat er informatie beschikbaar moet zijn met betrekking tot de leeftijdsopbouw, intrede, uittrede en herintrede naar specifieke beroepsgroepen en naar provincie. 


\section{Conclusie}

Het verkennende onderzoek waarvan dit rapport verslag wordt gedaan heeft ten doel gehad om de mogelijkheden te onderzoeken om deelmarktinformatie en deskundigheid in het informatiesysteem onderwijs-arbeidsmarkt in te passen. Externe expertise kan mogelijk een rol vervullen bij het vooraf toetsen van de plausibiliteit van de door het ROA opgestelde prognoses. Het opnemen van deelmarktinformatie kan er bovendien mogelijk toe leiden dat de ROA-prognoses op een lager aggregatieniveau gepresenteerd kunnen worden, wat vooral ten goede zou kunnen komen aan heterogeen samengestelde beroepsklassen en opleidingstypen. Deze deelmarktinformatie zou het beste verkregen kunnen worden door het inschakelen van externe expertise.

In hoofdstuk 2, waarin verslag is gedaan van een inventarisatie van de bestaande 'judgemental forecasting' literatuur, is naar voren gekomen dat het inschakelen van externe experts met de nodige voorzichtigheid moet worden benaderd. Uit onderzoek van McNees (1990) is gebleken dat experts geneigd zijn om teveel gewicht te geven aan specifieke actuele omstandigheden. Uit een aantal onderzoeken is tevens naar voren gekomen dat onder sterk afgebakende grenzen het combineren van modellen met expertise tot betere resultaten kan leiden.

Het CPB maakt ook gebruik van een combinatie van econometrische modellen en meer kwalitatieve expertise bij het maken van de bedrijfstakprognoses. Het CPB heeft hiervoor echter interne deskundigheid ontwikkeld. Dit betekent dat een aantal personen zich bezighoudt met de ontwikkelingen in een bepaalde bedrijfstak door het bestuderen van de relevante literatuur en regelmatige contacten met personen in het desbetreffende werkveld. De meningen van de interne deskundigen verschillen doorgaans ook met de modeluitkomsten. Op basis van de resultaten van een dan te voeren discussie wordt de prognose vervolgens aangepast.

Verder is in hoofdstuk 2 gebleken dat de dictator-methode het meest voor de hand ligt om met externe experts te werken, maar dat door de nodige praktische problemen het ondoenlijk is deze methode daadwerkelijk toe te passen. Bovendien is het bij deze methode zeer twijfelachtig of de kosten van het inschakelen van deze expertise opwegen tegen de baten ervan. Een second-best-optie is de dialecticmethode, waarbij de ROA-prognoses worden voorgelegd aan een algemeen-deskundige met betrekking tot een bepaald beroeps- of opleidingssegment van de arbeidsmarkt. Ten slotte zijn in hoofdstuk 2 twee belangrijke factoren onderscheiden om arbeidsmarktsegmenten te selecteren die in aanmerking komen voor deskundigenraadpleging, te weten: de kwaliteit van de ROA-prognoses en de heterogeniteit van beroeps- en opleidingssegmenten. De combinatie van beide elementen is immers bepalend voor de accuraatheid van de prognoses.

In hoofdstuk 3 zijn de aandachtspunten binnen het ROA-informatiesysteem beschreven. Voor zowel de beroepsklassen als de opleidingstypen is aan de hand van het rapport Evaluatie arbeidsmarktprognoses naar opleiding en beroep in 1992 een inventarisatie gemaakt van de probleemsegmenten binnen het informatiesysteem onderwijs-arbeidsmarkt. Hierbij zijn ook de onderliggende prognoses van de uitbreidingsvraag, de vervangingsvraag en de baanopeningen naar beroep en/of opleiding nader geanalyseerd. In het hoofdstuk valt op dat de voorspelfouten zich niet duidelijk op een bepaald deel van de arbeidsmarkt concentreren. Verder blijken de prognoses van de arbeidsmarktperspectieven van opleidingstypen aanmerkelijk beter uit te vallen dan voor de onderliggende vraagprognoses naar beroepsklasse. Er kan dan ook geconcludeerd worden dat met name het zoeken naar extra expertise c.q. verklarende variabelen voor de werkgelegenheids-ontwikkeling op beroepsklasse niveau over een zo breed mogelijk deel van de arbeidsmarkt is gewenst. 
In hoofdstuk 4 zijn de mogelijke bronnen van externe expertise in kaart gebracht. Er zijn een zestal bronnen onderscheiden, te weten: branche-gelieerde onderzoeksinstellingen, werkgeversverenigingen, branche-gelieerde onderwijsinstellingen, beroepsverenigingen, overheidsorganen en particuliere instellingen die zich bezighouden met niet-regulier onderwijs. Vervolgens is het begrip kwaliteit van deskundigheid geoperationaliseerd. Mede op basis daarvan is een vijftal organisaties geselecteerd om een verkennend gesprek mee te voeren.

Uit de gesprekken met vertegenwoordigers van instellingen met belangrijke potentiële externe expertise, kan worden afgeleid dat het opzetten van een extern netwerk rondom de arbeidsmarktprognoses naar opleiding en beroep een moeizaam proces zal zijn. De benaderde organisaties beschikken slechts in beperkte mate over voor het ROA van belang zijnde data of expertise, terwijl één organisatie niet bereid was data of expertise af te staan ten behoeve van het informatiesysteem. Dit is een duidelijke illustratie van de complexiteit van het opzetten van een netwerk van externe expertise. Bovendien komt duidelijk naar voren dat de expertise op het gebied van onderwijs en arbeidsmarkt bij de meeste branche-, beroep- of opleiding-gelieerde organisaties slechts zeer fragmentarisch is. Het lijkt dan ook weinig zinvol om de ROA prognoses structureel aan een aantal instellingen of personen voor te leggen met een verzoek om commentaar. Ook op het gebied van de segment-specifieke data lijkt er niet zo veel externe informatie voorhanden.

Natuurlijk dient te worden opgemerkt dat slechts een beperkt aantal instellingen is benaderd. Dit zou kunnen betekenen dat binnen andere instellingen nog wel data en/of expertise aanwezig kan zijn die bruikbaar is voor het informatiesysteem onderwijs-arbeidsmarkt. Voor instellingen als het NIBI en het $\mathrm{NZi}{ }^{5}$ kan dit zelfs met grote zekerheid worden gesteld. Echter, het staat bij veel organisaties op voorhand ook haast wel vast dat er weinig of geen kennis aanwezig is met betrekking tot de toekomstige arbeidsmarktsituatie. Verwacht mag worden dat de bij deze instellingen beschikbare informatie doorgaans niet meer zal opleveren dan een incidentele voetnoot over ontwikkelingen op een lager aggregatieniveau in de rapportage, zoals in het verleden ook gedaan is bij de opleidingstypen $\mathrm{HBO}$ onderwijs, WO onderwijs en $\mathrm{HBO}$ technische bedrijfskunde.

Een mogelijke oplossing voor het absorberen van de beschikbare, doorgaans weinig systematische en sterk fragmentarische arbeidsmarktsegmentspecifieke informatie, is de door het CPB en SCP gehanteerde aanpak ${ }^{6}$. Binnen het ROA zelf zou deze segmentspecifieke expertise ontwikkeld kunnen worden, waarbij gebruik wordt gemaakt van de beschikbare externe expertise. Dit betekent dat enkele ROA-medewerkers zich op bepaalde arbeidsmarktsegmenten zullen moeten specialiseren, door middel van het bijhouden van de relevante literatuur en het onderhouden van diverse externe contacten. Deze netwerk-methode is echter erg arbeidsintensief en zal dus ook de nodige kosten met zich meebrengen. Een voordeel van deze methode is overigens wel dat het ROA het aanspreekpunt kan worden op het gebied van veranderende arbeidsmarktposities van bepaalde beroepsklassen en/of opleidingstypen. Bovendien kan op deze wijze binnen het ROA meer expertise ontstaan over het hoe en waarom van bepaalde segmentspecifieke arbeidsmarktontwikkelingen. Dit alles kan de kwaliteit van de prognoses zeer ten goede komen. Er zal echter een gedegen afweging dienen te worden gemaakt met betrekking tot de kosten en baten van een dergelijke aanpak.

5. Onlangs is door het ROA op viij grote schaal gebruik gemaakt van de bij het NZi beschikbare data voor verpleegkundigen en verzorgenden (zie De Grip c.s., 1994).

6. Ook het Bureau of Labor Statistics in de Verenigde Staten volgt deze werkwijze bij het opstellen van haar arbeidsmarktprognoses naar beroep. 
Binnen een dergelijke aanpak zouden ook bepaalde prognose-uitkomsten aan externe deskundigen kunnen worden voorgelegd. Naast het voordeel dat daardoor in sommige gevallen voorkomen zou kunnen worden dat een bepaalde te verwachten ontwikkeling over het hoofd wordt gezien, kan dit bovendien als voordeel hebben dat de acceptatie van de prognoses binnen het desbetreffende werkveld zelf wordt vergroot. 



\section{Literatuur}

Ahlburg, D.A., K.C. Land, Population forecasting: Guest Editors' introduction, International Journal of Forecasting, 8 (1992), pp. 289-299.

Armstrong, J.S. (1985), Long-range forecasting, John Wiley, New York.

Borghans, L., P. van Eijs, A. de Grip (1994), Evaluatie arbeidsmarktprognoses naar opleiding en beroep in 1992, ROA-R1994/4, Maastricht.

Borghans, L., H. Heijke (1993), Forecasting the educatioal structure of occupations: a manpower requirement approach with substitution, ROA-RM-1993/2E, Maastricht.

Borghans, L., J. Hoevenberg (1994), De arbeidsmarkt voor een studierichting Biomedische Technologie, ROA-R-1994/9, Maastricht.

Borghans, L., M.R. Wiendels (1993), De abeidsmarktperspectieven voor Maastrichtse psychologen. Een vooronderzoek, ROA-R-1993/8, Maastricht.

Collopy, F., J.S. Armstrong, Expert opinions about extrapolation and the mystery of the overlooked discontinuities, International Journal of Forecasting, 8 (1992) , pp. 575-582.

CPB (1983), Kompas; Kwartaalmodel voor prognose, analyse en simulatie, DOP, 's-Gravenhage.

CPB (1990), Athena, Een bedrifstakkenmodel voor de Nederlandse Economie. CPB Monografie 30, 's-Gravenhage.

CPB (1992), FKSEC, a macro-econometric model for the Netherlands, Stenfert Kroese, Leiden.

EIB (1993), Het arbeidsbestand in de bouwnijverheid in 1992, Amsterdam.

Grip, A. de, H. Berendsen, L. Borghans, R.J.P. Dekker (1993), Toekomstverkenning leerlingwezen, ROA-R-1993/4, Maastricht

Grip, A. de, J.A.M. Heijke, H. Berendsen (1991), Eerste evaluatie informatiesysteem onderwijs-arbeidsmarkt, ROA-R1991/1, Maastricht.

Grip, A. de, E.J.T.A. Willems, J. Hoevenberg, P.J.E. van de Loo (1994), A.G.M. Matheeuwsen, Toekomstverkenning arbeidsmarkt zorgsector, ROA-R-1994/6, Maastricht.

Harmsen, J., L. Hingstman, M.J. Driessen (1993), Behoefteraming Ergotherapeuten 1993, NIVEL, Utrecht.

Hingstman, L., J.B. Pool, R. Barentsen (1992), Behoeftebepaling gynaecologen/obstetrici, NIVEL, Utrecht.

Hughes (1993), Projecting the occupational structure of employment in OECD countries, OECD labour market and social policy occasional occasional papers no. 10, Paris.

Kranenborg, A., J. Stroo (1993), De bouwarbeidsmarkt in de periode 1991-1998 naar provincie en beroepsgroep, EIB, Amsterdam.

Kruisinga, A., G.W.M. Ramaekers, R.K.W. van der Velden (1993), Marktverkenning European Law School, ROA-R-1993/11, Maastricht.

McNees, S.K., The role of judgment in macroeconomic forecasting accuracy, International Journal of Forecasting, 6 (1990), pp. 287-299.

O'Connor, M., W. Remus, K. Griggs, Judgemental forecasting in times of change, International Journal of Forecasting, 9 (1993), pp. 163-172.

ROA (1993), De arbeidsmarkt naar opleiding en beroep tot 1998. Statistische bijlage, ROA-R-1993/10B, Maastricht.

Sniezek, J.A., An examination of group process in judgmental forecasting, International Journal of Forecasting, 5 (1989), pp. 171-178. 



\section{Bijlage A.}

Informatiebronnen en contactpersonen met betrekking tot de ROA beroepsklassen

ROA-code Beroepsklasse Informatiebron/contactpersoon

0

0131

0132

0133

0221

1

1131

1231

1321

1331

2

2011

2012

3

3011

3012

3021

3022

3023

3031

3111

3112

3211

3212

3213

3311

3312

3411

3511

3611

3612

3613

3614

3615

3621

3622

3631

3711

3721

3731

3811

3911

3912

3913

3915

3921

3931
Pedagogische Beroepen

leerkrachten basis- en speciaal onderwijs

docenten voortgezet en hoger onderwijs

schoolhoofden e.a. onderwijskundige beroepen

sportinstructeurs, officials, beroepssportlieden

Culturele beroepen

taal- en letterkundigen, vertalers, tolken

pastorale beroepen

fotografen, filmers, vormgevers, etaleurs

beeldende en uitvoerende kunstenaars

\section{Agrarische beroepen}

uitvoerend agrarisch personeel, bosarbeiders

zelfstandige agrariërs, boswachters

Techniche, ambachts- en industrieberoepen

heftruck- en hefvorkchauffeurs

machinisten bouw en industrie

directeuren, bedrijfsleiders, leidinggevenden industrie

technische en medische vertegenwoordigers

technische tekenaars

bètaonderzoekers, technische vakspecialisten

voedingsmiddelenbereiders

(zelfstandige)bakkers e.a. (industrieel) bakkerijpersoneek

produktiepersoneel textielindustrie

stoffeerders, schoen- e.a.lederwarenmakers

kleding- e.a. textiel en bontprodukten makers

houtzagers, hout(waren)-, papier- en kartonmakers

houtbewerkers, timmerlieden

drukkers, boekbinders, fotolaboranten

produktiepersoneel chemische industrie

delfstoffen(be)werkers, metaalvervaardigers

machinale metaalbewerkers

lassers, constructiewerkers, edelmetaalsmeden

machinebank- en plaatwerkers, gereedschaps- en modelmakers

onderhoudsmonteurs, fietsen- en instrumentmakers

auto-, motor- en bromfietsmonteurs

middelbare (scheeps)werktuigkundige e.a. metaalkundigen

hogere werktuigkundigen

samenstellers elektro-technische produkten, kwaliteitscontroleurs

electriciens, elektro-telecom(onderhouds)monteurs

hogere elektrotechnici

produktiepersoneel bouwmaterialen-, glas- en aardewerkindustrie

metselaars, tegelzetters, straatmaker, stukadoors

betonwerkers, dakdekkers, isoleerders, glaszetters

huis-, scheeps- en constructeschilders

overige bouwvaklieden, (spoor)weg- en reinigingswerkers

bouwkundige technici, opzichters, werkvoorbereiders

architecten geodeten e.a. hogere bouwkundigen
Sociaal Cultureel Planbureau

Ministerie OC\&W/IVA

idem

idem

\section{LEI/NILI/STOAS}

idem

idem

EIB

SVGB

Min. Economische Zaken/ROA,NIBI, KNCV, KIVI

SVEB, VBOV,EIM

Fenecon, VOCON

VAS

Fenecon, VOCON

EIB

KVGO

VAPRO

FME, SOM

FME, SOM

FME, SOM

FME, SOM

BOVAG, EIM, VOCar

EIM, BOVAG, VOCar

SVZ/SLHV

KIVI/NIRIA

VEVIUNETO

KIVI, NIRIA

EIB

EIB

EIB

EIB

KIVI,NIRIA 


ROA-code Beroepsklasse Informatiebron/contactpersoon

4

\section{Transportberoepen}

laders, lossers, vul- en inpak(machine)bedienden

matrozen e.a. scheepsdek- en machinekamerpersoneel

scheepsofficieren, loodsen, walinspecteurs

conducteurs, chauffeurs ea transportmiddelenbestuurders

vliegers, boordwerktuigkundigen, transportdienstleiders

\section{Medische en paramedische beroepen}

gediplomeerde verpleegkundigen, verloskundigen

leerling-verpleegkundigen, zieken- en kraamverzorgenden

dokters-, tandarts- en dierenartsassistenten

apothekersassistenten, opticiens, orthopedisten

EEG-laboranten, keurmeesters, diëtisten, logopedisten, pedicuren etc fysio-, arbeids- e.a. bewegingstherapeuten

radiologisch, medische en biologische laboranten

geneeskundigen, medisch adviseurs, apothekers

tandheelkundigen en tandheelkundige specialisten

\section{Economisch-administratieve beroepen}

hogere leidinggevende

postdistributiepersoneel

datatypisten, computeroperators

administratief leidinggevenden

secretaressen, typisten

bibliotheekassistenten

boekhoudkundige, belasting-, loket- en bankemployees

commercieel-administratieve employees

telefonisten, balie-employees, enqueteurs e.d.

systeemanalysten, -programmeurs en -beheerders

accountants, economen e.a. economische specialisten

winkel-, straat- en marktverkopers, demonstrateurs

winkeliers e.a. detail- en groothandelaren

in-/verkoopchefs, handels- en verzekeringsagenten, makelaars e.d.

leden en leidinggevenden openbaar bestuur, beleidsambtenaren

juristen

\section{Sociaal-culturele beroepen}

auteurs, journalisten, nieuwslezers, presentatoren

bibliothecarissen, archivarissen, conservatoren

personeels- en beroepenspecialisten, arbeidsbemiddelaars

maatschappelijk werkers, reclasseringsambtenaren

sociale wetenschapsbeoefenaren

overige sociaal-culturele en commerciële vakpecialisten

Verzorgende en dienstverlenende beroepen

koks, kelners e.a. keuken- en serveerpersoneel

houders en leidinggevenden horeca- en recreatiebedrijven

portiers, schoonmaak- e.a. lager dienstverlenend personeel

kinder-, gezins-, bejaardenverzorgenden e.a. verzorgend personeel

kappers, schoonheidsspecialisten

Openbare orde en veiligheden

politie-, brandweer- en bewakingspersoneel

beroepsmilitairen

\section{SLHVISVZ \\ MARIN \\ MARIN \\ EBW \\ RLD}

NZI, NZf, NIZW, KNMG, Min. VWS

Min. WWS/ROA, LVT

SCP, OVDB, NZi, LVT

NIVEL, Min. WWS

NIVEL

NIVEL, NVD, NVLF

NIVEL, KNGF

NRV, SVGB

NIVEL, STG, NRV, LHV, LAD, LSV,KNMG,

KNMP

NVT

PTT

NIVRA

EIM, IMK

EIM, IMK

Ministerie van Binnenlandese Zaken

NOB

SCP

CBA

SCP

EIM/Bedrijfsschap Horeca/

Onderwijscentrum Horeca

EIM

ROAWWC; SCP (PPK-project), SCRG EIM, SVK

Ministerie van Binnenlandse Zaken Ministerie van Defensie 


\begin{tabular}{|c|c|c|}
\hline SOI-code & Opleidingstype & Informatiebron/contactpersoon \\
\hline $0,1,2$ & BASISONDERWIJS & \\
\hline $000,111,201$ & basisonderwijs & $\mathrm{CPB}$ \\
\hline 3 & MAVO, LBO & \\
\hline 301 & mavo en onderbouw havo/vwo & $\mathrm{CPB}$ \\
\hline 321-329 & Ibo agrarisch & $\begin{array}{l}\text { LEI, VOLLT, SPLBC, STOAS, } \\
\text { Ministerie van Landbouw en Visserij, AOC-raad }\end{array}$ \\
\hline 331-339 & Ibo technisch & $\mathrm{CPB}$ \\
\hline 341-349 & Ibo haven en vervoer & EBWIMARIN \\
\hline 361-369 & Ibo economisch administratief & IMKO \\
\hline 381-389 & Ibo verzorgend & CPB \\
\hline 391-394 & Ibo beveiliging en bewaking & EIM, PBNA, IVOB \\
\hline 4 & HAVO/VWO, MBO & \\
\hline 401 & bovenbouw havo/vwo & CPB \\
\hline $421-429$ & mbo agrarisch & $\begin{array}{l}\text { LEI, Ministrie van Lanbouw en Visserij, AOC- } \\
\text { raad, SPLBC }\end{array}$ \\
\hline 431 & mbo technisch laboratorium & SVGB \\
\hline $436-439$ & mbo technisch & $\begin{array}{l}\text { CPB, GOC, INNOVAM, Betex, SOI, SOM, SVB, } \\
\text { VAPRO, SVS, VEV }\end{array}$ \\
\hline $441-449$ & mbo haven en vervoer & EBW, MARIN, SLHV, KOF, OVD, DLW, VBOB \\
\hline 452 & mbo medisch laboratorium & SVGB \\
\hline 451,454 & mbo verpleging en ziekenverzorging & NZi, Ministerie van WVC/SCP, OVDB, SSSV \\
\hline $453,461-464$ & mbo economisch \& administratief & IMKO, EKON, ECABO, SW \\
\hline 466 & mbo bestuurlijk & $\mathrm{ROI}$ \\
\hline 471 & mbo sociaal-cultureel & SCP \\
\hline $481,484,486$ & mbo verzorgend & CPB/ROAWWC \\
\hline 483 & mbo horeca \& kappers & EIM, VBOB, Onderwijscentrum Horeca \\
\hline \multirow[t]{2}{*}{ 491-494 } & mbo politie $\&$ defensie & Ministerie van Defensie \\
\hline & & Ministerie van Binnenlendse Zaken \\
\hline 5 & HBO & \\
\hline 506 & hbo onderwijs & Ministerie van OC\&W/IVA \\
\hline 511 & hbo tolk \& vertaler & \\
\hline 516 & hbo theologisch & \\
\hline $521-529$ & hbo agrarisch & LEI \\
\hline 531 & hbo technisch laboratorium & \\
\hline $536-539$ & hbo technisch & CPB/NIRIA \\
\hline $541-549$ & hbo vervoer & EBW/MARIN \\
\hline 552 & hbo medisch laboratorium & \\
\hline 551,554 & hbo verpleging \& paramedisch & NRV, ROAMVC,SSSV \\
\hline 561 & hbo economisch-administratief & $\mathrm{CPB}$ \\
\hline 562 & hbo technische bedrijfskunde & \\
\hline 566 & hbo bestuurlijk & ROI \\
\hline 571 & hbo sociaal-cultureel & SCP \\
\hline 586 & hbo kunst & \\
\hline \multirow[t]{2}{*}{591} & hbo politie \& defensie & Ministerie van Defensie \\
\hline & & Min. Binnenlandse Zaken \\
\hline 6 & wo & \\
\hline 606 & wo onderwijs & Min. OC\&W/IVA \\
\hline 611 & wo humaniora & \\
\hline 616 & wo theologisch & \\
\hline \multirow[t]{2}{*}{$621-6219$} & wo agrarisch & LEI; St. Maatschappelijke Plaats \\
\hline & & Landbouwingenieurs Wageningen \\
\hline 631 & wo wis- en natuurkunde & $\mathrm{VNCl}$, Nederlands Wiskundig Genootschap \\
\hline 636-639 & wo technisch & CPB; KIVI; KNCV;NIBI \\
\hline 651 & wo dier-/genees-/tandheelkunde & SCP, NIVEL, STG, NRV \\
\hline
\end{tabular}


661-662

666

671

686 wo econom(etr)ie \& bedrijfskunde

wo rechten \& bestuurskunde

wo sociaal-cultureel

wo kunst 